\title{
FRACTURE OF BRITTLE MATERIALS AT HIGH TEMPERATURE
}

\author{
N. J. TIGHE \\ S. M. WIEDERHORN
}

FRACTURE AND DEFORMATION DIVISION

NATIONAL MEASUREMENT LABORATORY

NATIONAL BUREAU OF STANDARDS

WASHINGTON, D.C. 20234

JULY 1978

TECHNICAL REPORT AFML-TR-78-83

Final Report for Period January 1976 - December 1977

Approved for public release; distribution unlimited.

AIR FORCE MATERIALS LABORATORY

AIR FORCE WRIGHT AERONAUTICAL LABORATORY

AIR FORCE SYSTEMS COMMAND

WRIGHT-PATTERSON AIR FORCE BASE, OHIO 45433 
When Government drawings, specifications, or other data are used for any purpose other than in connection with a definitely related Government procurenent operation, the United states Government thereby incurs no responsibility nor any obligation whatsoever; and the fact that the goverment may have formulated, furnished, or in any way supnlied the said arawings, specifications, or other data, is not to be regarded by implication or othervise as in any manner licensing the holder or any other person or corporation, or conveying any rights or permission to manufacture, use, or sell any patented invention that may in any way be related thereto.

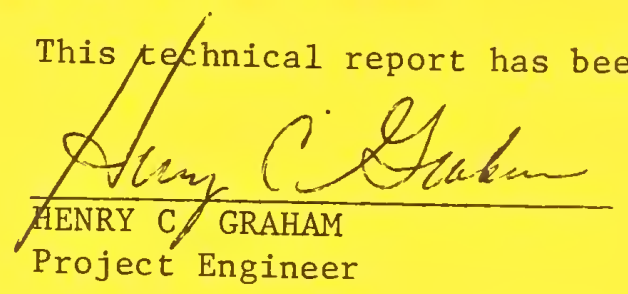

approved for publication.

FOR THE COMMANDER

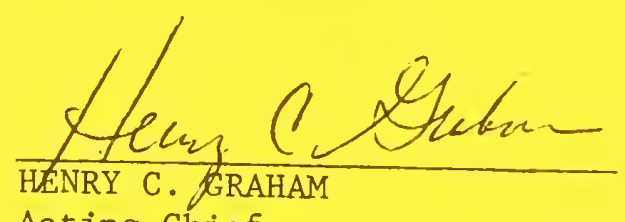

Acting Chief

Processing and High Temperature Materials Branch

Metals and Ceramics Division

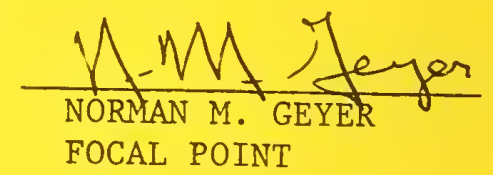

"If your address has changed, if you wish to be removed from our mailing list, or if the addressee is no longer emrloyed by you organization please notify AFML/LLM , W-P AFB, OH 45433 to help us maintain a current mailing list".

Copies of this report should nct be returned unless return is required by security considerations, contractual obligations, or notice on a specific cocument. AIR FORCE/56780/9 January $1979-135$ 


\begin{tabular}{|c|c|}
\hline REPORT DOCUMENTATION PAGE & $\begin{array}{l}\text { READ INSTRUCTIONS } \\
\text { BEFORE COMPLETING FORM }\end{array}$ \\
\hline $\begin{array}{l}\text { 1. REPORT NUMBER } \\
\text { AFML-TR-78-83 }\end{array}$ & 3. RECIPIENT'S CATALOG NUMBER \\
\hline \multirow{2}{*}{$\begin{array}{l}\text { 4. TITLE (and Subtitie) } \\
\text { Fracture of Brittle Materials at High } \\
\text { Temperature }\end{array}$} & $\begin{array}{l}\text { S. TYPE OF REPORT \& PERIOO COVERED } \\
\text { Final Report } \\
\text { January } 1976 \text {-December } 1977\end{array}$ \\
\hline & 6. PERFORMING ORG. REPORT NUMBER \\
\hline $\begin{array}{l}\text { 7. AUTHOR(s) } \\
\text { N. J. Tighe and S. M. Wiederhorn }\end{array}$ & $\begin{array}{l}\text { 8. CONTRACT OR GRANT NUMBER(s) } \\
\text { F33615-76-F-6752 }\end{array}$ \\
\hline \multirow{2}{*}{$\begin{array}{l}\text { 9. PERFORMING ORGANIZATION NAME AND ADDRESS } \\
\text { Fracture and Deformation Division } \\
\text { National Measurement Laboratory } \\
\text { National Bureau of Standards } \\
\text { Washington, D. C. } 20234 \\
\end{array}$} & $\begin{array}{l}\text { 10. PROGRAM ELEMENT, PROJECT, TASK } \\
\text { AREA \& WORK UNIT NUMBERS }\end{array}$ \\
\hline & $\begin{array}{l}2306 \mathrm{P} 203 \\
61102 \mathrm{~F}\end{array}$ \\
\hline \multirow{2}{*}{$\begin{array}{l}\text { 11. CONTROLLING OFFICE NAME AND ADDRESS } \\
\text { Air Force Materials Laboratory } \\
\text { Wright-Patterson AFB, Ohio } 45433\end{array}$} & $\begin{array}{l}\text { 12. REPORT DATE } \\
\text { JU1Y } 1978\end{array}$ \\
\hline & $\begin{array}{l}\text { 13. NUMBER OF PAGES } \\
45\end{array}$ \\
\hline \multirow[t]{2}{*}{ 14. MONITORING AGENCY NAME \& ADORESS(if different from Controlling Office) } & $\begin{array}{l}\text { 15. SECURITY CLASS. (of this report) } \\
\text { Unclassified }\end{array}$ \\
\hline & $\begin{array}{l}\text { iSa. DECLASSIFICATION/DOWNGRADING } \\
\text { SCHEDULE }\end{array}$ \\
\hline
\end{tabular}

16. DISTRIBUTION STATEMENT (of this Report)

Approved for Public Release: Distribution Unlimited.

17. DISTRIBUTION STATEMENT (of the abstract entered in Block 20, if different from Report)

18. SUPPLEMENTARY NOTES

19. KEY WORDS (Continue on reverse side if necessary and identify by block number)

Proof Testing; silicon nitride; ceramic turbine; strength; high temperature;

flaw generation; oxidation; strength degradation; hot-pressed $\mathrm{Si}_{3} \mathrm{~N}_{4}$;

reaction bonded $\mathrm{Si}_{3} \mathrm{~N}_{4}$

20. ABSTRACT (Continue on reverse side if necessary and ldently by block number) 

FOREWORD

This report is the final technical report on "Fracture of Brittle Materials at High Temperatures" sponsored by the Air Force Materials Laboratory, AFSC under Contract F33615-76-F-6752. The program was funded for two years.

The principal investigators were Drs. Nancy J. Tighe and Sheldon M. Wiederhorn. Mr. Lewis Russell assisted in obtaining the test results. The technical monitor was Dr. Norman Tallan of AFML. 
TABLE OF CONTENTS

PAGE

INTRODUCTION

EXPERIMENTAL PROCEDURE

EXPERIMENTAL RESULTS

DISCUSSION OF RESULTS

CONCLUSIONS

REFERENCES

TABLES

39

PUBLICATIONS

41 


\section{LIST OF TABLES}

TABLE

PAGE

1

MEAN STRENGTH OF TEST MATERIALS

7

2

STRENGTH OF INDENTED SPECIMENS: $2 \mathrm{~kg}$ LOAD

17 


\section{LIST OF ILLUSTRATIONS}

\section{FI GURE}

DESIGN DIAGRAM, PROOF STRESS VS. SERVICE STRESS

2 HYDRAULIC LOADING APPARATUS

3 WEIBULL PLOT SHOWING EFFECT OF PROOF TESTING ON STRENGTH DISTRIBUTION

4 EFFECT OF PROOF TESTING ON STRENGTH DISTRIBUTION AT $25^{\circ} \mathrm{C}$

EFFECT OF PROOF TESTING ON STRENGTH DISTRIBUTION AT $1200^{\circ} \mathrm{C}$

EFFECT OF $1200^{\circ} \mathrm{C}$ EXPOSURE ON ROOM TEMPERATURE STRENGTH

EFFECT OF $1200^{\circ} \mathrm{C}$ EXPOSURE ON STRENGTH OF NC 132 BILLET A

EFFECT OF $1200^{\circ} \mathrm{C}$ EXPOSURE ON STRENGTH OF NCX34

EFFECT OF $1200^{\circ} \mathrm{C}$ EXPOSURE ON STRENGTH OF NC 132 BILLET B

13 SCANNING ELECTRON MICROSCOPIC EXAMINATION OF SURFACE PIT IN OXIDE LAYER

14 MICROGRAPH OF PIT AS A FRACTURE SOURCE IN HOT-PRESSED SILICON NITRIDE

15 MOUND FORMED DURING $1200^{\circ} \mathrm{C}$ EXPOSURE OF NC 132 BILLET B

16 SCHEMATIC DRAWING ILLUSTRATING EFFECT OF OXIDATION ON FLAWS IN $\mathrm{Si}_{3} \mathrm{~N}_{4}$

17 ROOM TEMPERATURE STRENGTH DISTRIBUTION FOR HOT-PRESSED AND REACTION BONDED MATERIALS HOT-PRESSED AND REACTION BONDED MATERIALS 
SECTION I

Introduction

Program Plan

Ceramic materials offer the potential for significantly increased operating temperatures, increased efficiency and lower costs for gas turbine engines. However, the brittle nature and resulting catastrophic mode of failure of ceramic materials requires a design approach based on consideration of crack nucleation and growth [1-11]. If both the initial size of pre-existing cracks and the rate at which they grow under an applied stress are known then the time to reach critical size at which failure occurs can be predicted. In principle, the initial size can be determined by non-destructive test techniques. However, state-of-theart NDT equipment does not have the required sensitivity to detect the flaws in question, which are generally 100 um or less. An upper limit on tolerable flaw size can be obtained by proof testing, but the validity of this approach needs to be demonstrated. There is little information on the strength of turbine ceramics which can be used for component design and the relationship between material behavior and microstructure is not well understood.

The major objective of the proposed research was to demonstrate that proof testing could be used to assure the reliability or lifetime of turbine components made from ceramic materials. The secondary objectives were: (1) the accumulation of critical stress intensity and crack growth data on new or improved turbine ceramics in order to generate proof test design diagrams and (2) the determination of the relationship between the microstructure and the observed fracture behavior. 
The technical requirements of the project were as follows: Fourpoint bend tests were conducted on two billets of Norton $\mathrm{NC}-132$, one billet of NCX-34 hot pressed silicon nitride and 5 billets of Norton NC350 reaction bonded silicon nitride. For each material, one set of specimens was used to determine fracture strength, a second set was used to determine whether proof testing truncated the fracture strength distribution, and a third set was used for time to failure measurements after a proof test was applied. The lifetimes were compared to components that received no proof tests. A statistical analysis was conducted to assess the reliability of the proof test technique. The crack growth rate and the critical stress intensity data required for the time to failure prediction were obtained by the double-torsion technique developed by Evans and Wiederhorn [4]. In addition, microscopic techniques were used to study microstructure and the fracture surfaces in order to determine the mechanisms responsible for crack growth and fracture. The studies were done both at room temperature and at the temperature expected in the gas turbine environment, that is $1200^{\circ} \mathrm{C}$. The area of primary emphasis was the validation of the proof test approach to the life prediction/life assurance of turbine ceramics.

\section{Proof Test Analysis}

Proof testing is one of the methods being considered as a means of improving the reliability of silicon nitride for turbine applications. Proof testing is used to eliminate weak components, which are most susceptible to failure in service, before they are placed in service. In a proof test, a load or proof test stress that is higher than that expected in service is applied to every component. This load breaks 
components that contain flaws greater than a certain maximum size and truncates the strength distribution of the surviving components.

The theory of proof testing provides a unique relation between the proof test stress, the service stress, and the predicted minimum time to failure in service $[5,7]$. This relationship can be expressed in design diagrams prepared from crack velocity data. These diagrams can be used by engineers to establish proof test levels for specific materials. In the diagram shown in Figure 1 , the proof test stress is selected for the

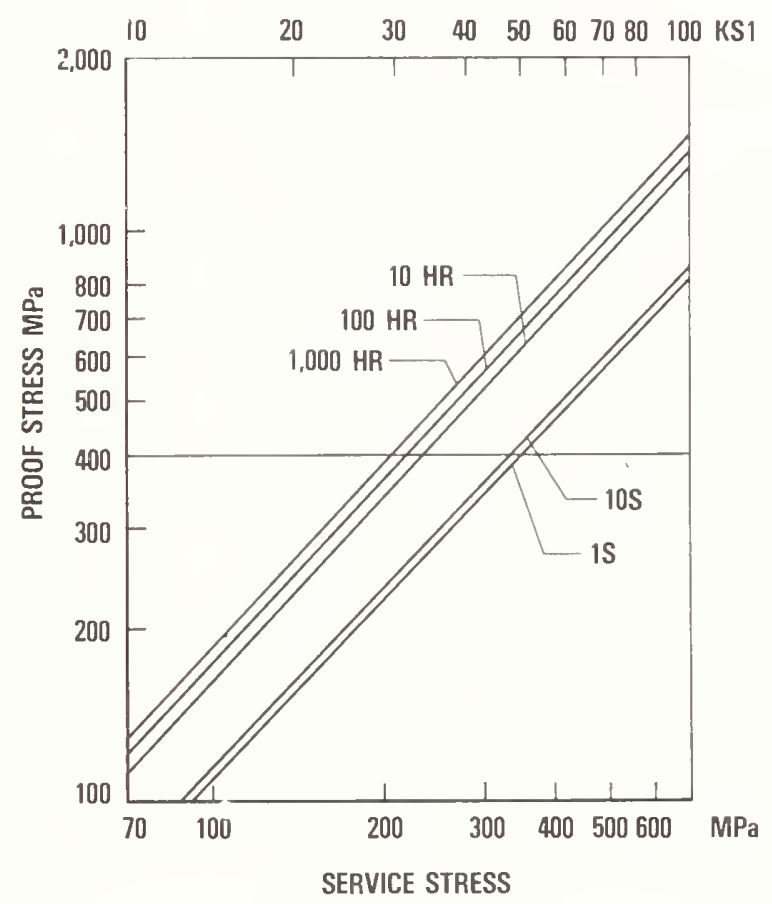

Figure 1. Proof test diagram for hot-pressed silicon nitride NC-132. This diagram is based on crack propagation data obtained in air at $1200^{\circ} \mathrm{C}$ (Ref. 18).

desired exposure time and the service stress. As a hypothetical example, if 100 hour service at $300 \mathrm{MPa}$ were required, then a proof stress of 560 MPa is determined, from Figure 1 , as the stress that would be necessary to assure full design lifetime of the components. 
The theory of proof testing assumes also that the population of flaws remains invarient after the proof test. Therefore if the flaw population changes during high temperature exposure, the effects of the exposure must be assessed before proof testing can be used as a viable screening procedure. High temperature exposure of silicon nitride in air is known to cause oxidation and strength degradation [12-17]. The present study has shown that oxidation can modify the flaw population and thus invalidate the lifetime predictions made by proof testing $[18,19]$. Therefore, to establish proof testing as a screening procedure, it is necessary to evaluate the proof test in an inert environment and to characterize the effect of high temperature oxidation on the flaw population by determining the change in the strength distribution of the silicon nitride after exposure. This report will be presented in the following scheme. In Section 11 the materials and test procedures will be presented. In Section III the results of proof tests, strength tests, and the effects of oxidation on the strength will be presented. In Section IV we discuss the results, the effects of the changing flaw population on strength, the statistical significance of the results and give some recommendations for further experimental work.

\section{SECTION II}

\section{Experimental Procedure}

\section{Materials}

Specimens were made from two billets of hot-pressed, magnesia-doped silicon nitride, one billet of yttria-doped silicon nitride, and five billets of reaction bonded silicon nitride. The specific specimen details are as follows: 
Hot Pressed $\mathrm{Si}_{3} \mathrm{~N}_{4} \mathrm{NC}-132$ - Two billets of magnesia doped hot pressed silicon nitride $(15.2 \times 15.2 \times 2.5 \mathrm{~cm})$ wert tested. These billets were manufactured at different times using different powder lots and are designated billet $A$ and billet $B$ in this report. Both billets had the nominal manufacturers* analysis in wt \% of: $0.20 \mathrm{Al}$; $0.05 \mathrm{Ca} ; 0.40-0.64 \mathrm{Fe} ; 0.70-0.74 \mathrm{Mg} ; 2.6-2.7 \mathrm{~W}$. Billet $\mathrm{A}$ was manufactured from powder lot HN5 which had the following manufacturers analysis in wt \%: $86.5 \alpha \mathrm{Si}_{3} \mathrm{~N}_{4}$;

$0.28 \mathrm{Al} ; 0.06 \mathrm{Ca} ; 0.39 \mathrm{Fe}$. Billet B was manufactured from powder lot HN8 which had the following manufacturers analys is in wt \%: $93.3 \alpha \mathrm{Si}_{3} \mathrm{~N}_{4} ; 0.14 \mathrm{Al} ; 0.04 \mathrm{Ca} ; 0.36 \mathrm{Fe} ; 1.340$. The magnesium addition was not given.

Thirty double-torsion specimens cut from Billet $A$ were used to obtain the K-V data in reference [17]; and 161 bars $(5 \times 4 \times 50 \mathrm{~mm})$ were cut and used in the proof test program. Billet B was cut into 322 bars $(4 \times 5 \times 50 \mathrm{~mm})$ for the proof test program. These bars were numbered with respect to their position in the billet, the numbers were randomized and the bars were tested in the order of the random numbers.

Reaction Bonded $\mathrm{Si}_{3} \mathrm{~N}_{4} \mathrm{NC}-350$ - Five billets of reaction bonded material $15.2 \times 15.2 \times 0.6 \mathrm{~cm}$, from the same powder lot and firing schedule were used for the tests. Each of the billets was cut into $\sim 72$ bars; the bars were numbered with respect to their position in the billet and the numbers randomized. The bars from each billet were tested in groups of 6 specimens so that a total of

\footnotetext{
Materials were obtained from the Norton Co., Worchester, Mass.
} 
30 specimens was used to obtain a complete distribution

of all billets. The strength distribution for the individual billets differed as shown by comparing the mean strengths listed in Table 1 . The strength distribution for all 5 billets was used to determine the proof test load. Hot-Pressed $\mathrm{Si}_{3} \mathrm{~N}_{4} \mathrm{NCX}-34$ - The billet of $\mathrm{Y}_{2} \mathrm{O}_{3}$ doped $\mathrm{Si}_{3} \mathrm{~N}_{4}(15.2 \times 15.2 \times 1.5 \mathrm{~cm})$ was cut to obtain 90 bars $4 \times 3 \times 50 \mathrm{~mm}$ for the proof test program and double-torsion specimens for crack velocity data. The proof test program was not completed before the project ended.

All test bars were ground along their lengths with a $180 \mathrm{grit}$ diamond wheel and the edges were retained. The test bars were prepared in this way to ensure obtaining a broad strength distribution for each material. Thus the mean strengths which are listed in Table 1 may be lower than values obtained in other studies on bars with chamfered edges or polished surfaces. The bars were numbered as they were cut according to a scheme so that the location of each bar in the billet was known. The bar numbers were radomized from a computer program which generated random numbers by swapping numbers for each set of bars 30,000 times. Thus each billet had a specific set of random numbers which was based on the number of bars per billet.

\section{Test Program}

The bars were tested in 4 -point bending, in air, at $25^{\circ} \mathrm{C}$ and $1200^{\circ} \mathrm{C}$. The SiC bend fixtures had upper and lower spans of 10 and $40 \mathrm{~mm}$ respectively. The upper temperature was selected after tests on the double-torsion specimens in Billet A showed that considerable plasticity and slow crack growth occurs above $1200^{\circ} \mathrm{C}$. Thus $1200^{\circ} \mathrm{C}$ is the maximum 
Flexure Strength, MPa

Material

NCl32 Billet A

NCl32 Billet B

NCX -34

NC350 Billet 6

Billet 7

Billet 8

Billet 9

Billet 10

Average 6-10 $25^{\circ} \mathrm{C}$

$670+99$

$635+108$

$880 \pm 52$

$214+33$

$206 \mp 41$

$259 \mp 34$

$181 \mp 34$

$262 \mp 71$

$225 \mp 52$ $1200^{\circ} \mathrm{C}(1 / 2 \mathrm{hr}$.

$534 \pm 44$

$524+71$

$785+58$

$297+53$

$278 \mp 50$

$274+65$

$206 \mp 38$

$342+68$

$278 \mp 68$

temperature at which this material can be used in high stress applications. In all tests, the bars were loaded at a cross head speed of $0.02 \mathrm{~cm}$ per minute. After proof testing, the bars were left on the test fixture and were loaded to failure after the various heat treatments without altering their position. In this way the stress distribution after proof testing was not changed during strength measurements. Proof test stresses were chosen to break approximately $50 \%$ of the test specimens for each experimental condition.

For high temperature tests, the furnace temperature was raised at the rate of $40^{\circ} \mathrm{C}$ per minute and the test specimens were equilibrated for $1 / 2$ hour at $1200^{\circ} \mathrm{C}$ before conducting strength measurements. It was found that oxidation significantly affected the test results presumably by changing the flaw population which controlled the strength. To study the effect of surface oxidation on the flaw population, strength measurements were made on specimens at $25^{\circ} \mathrm{C}$ and at $1200^{\circ} \mathrm{C}$ after different exposure times up to 100 hours. Additional strength measurements were 
made on specimens which had an artifical flaw introduced by indentation before exposure. Specimens were indented using a knoop indenter with a 2 kilogram load and were broken at 25 and $1200^{\circ} \mathrm{C}$ after exposure times of up to 100 hours at $1200^{\circ} \mathrm{C}$.

The strength studies at $1200^{\circ} \mathrm{C}$ were conducted in air and the silicon nitride surfaces oxidized during the test. It was necessary to characterize these oxidized surfaces in order to clarify our strength results. Light microscopy, and scanning and transmision electron microscopy were used to characterize the morphology of the surface oxide layer. In support of these studies, x-ray diffraction, electron diffraction, and energy dispersive $x$-ray analysis were used to identify the structure and chemical composition of the oxide coat. The microstructural changes which occurred as a result of exposure were correlated with the results of the strength measurements.

\section{Testing Apparatus}

Most of the experiments were carried out using a standard screw operated testing machine, (the Instron type). However, in order to perform experiments more efficiently, a special hydraulic loading test apparatus was designed and built so that three specimens could be broken independently in one furnace. Two furnaces (D) were set-up as in Figure $2 a$. Each test apparatus has 3 hydraulic cylinders (A) mounted below the furnace and 3 load cells (E) mounted above the furnace. Silicon carbide rods (C) attached to each load cell and cylinder with a water-cooled fixture (B), extend through the top and bottom of the furnace. Figure $2 b$ shows a set of three test bars in our standard 4-point bend $\mathrm{jigs}$ assembled inside the furnace. 
The load is applied to each specimen individually and the output is recorded. The loading rate was established by adjusting the oil pressure to obtain a displacement rate which was equivalent to the displacement rate used in the standard machine. The data obtained with this apparatus compared well with that obtained in the standard machine and the results were reproducible.

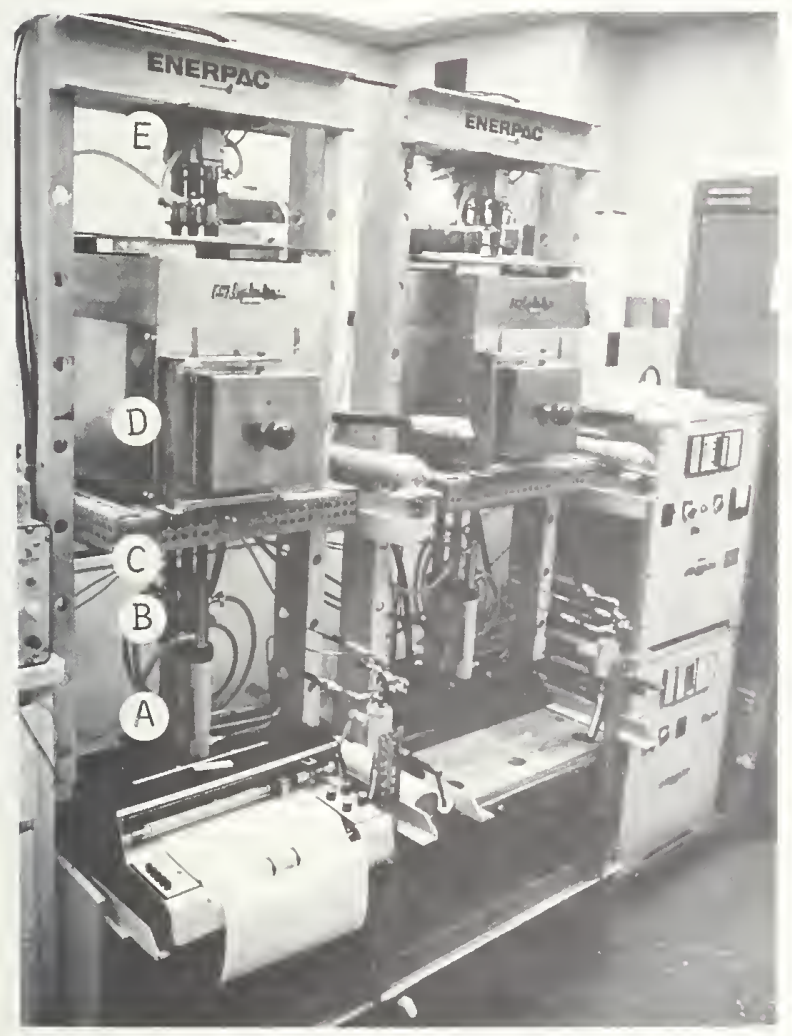

(a)

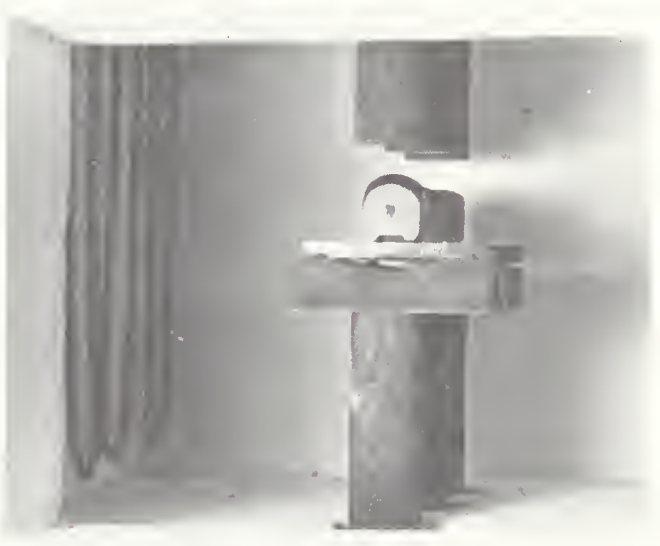

(b)

Figure 2. Hydraulic loading apparatus used to test 3 specimens in one furnace (a) furnace and loading arrangements; (b) interior of furnace showing 3 specimens in place. 
The results of the proof test will be displayed in the form of Weibull diagrams in which the strength values are ordered and plotted as a function of the failure probability [7,21]. The diagram in Figure 3 shows the scheme of initial and final strength distributions which should be obtained in proof testing. In our experiments, the initial or inert population is obtained by breaking specimens at $25^{\circ} \mathrm{C}$. This population is "inert" when no slow crack growth or plasticity occurs. After obtaining

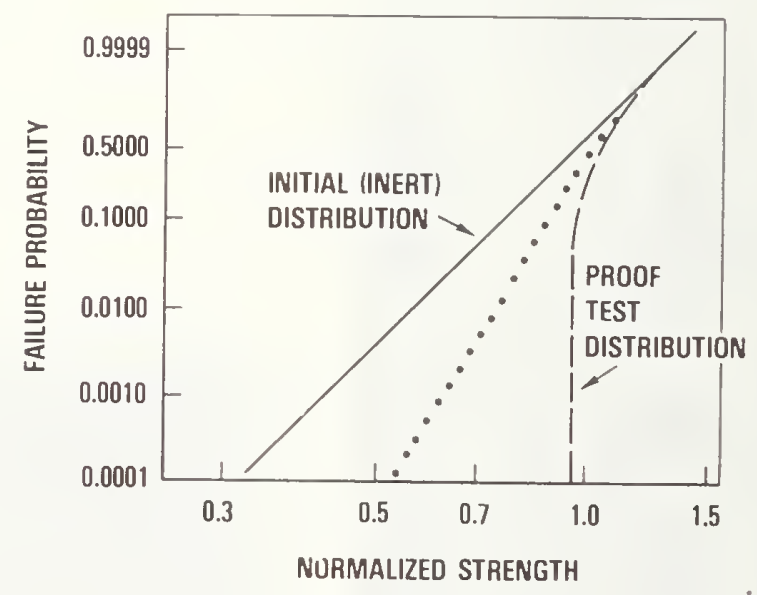

Figure 3. Weibull type probability plot demonstrating the effect of proof testing on strength distribution: - initial inert distribution; --- proof test in an inert environment; ... proof test in an environment in which subcritical crack growth can occur.

this initial inert strength distribution a stress is chosen that will break approximately $50 \%$ of the population. When the survivors of the proof test are broken the strength of the suviving specimens should be higher than this proof stress. Thus when these strength values are 
ordered and plotted on the Weibull diagram the strengths appear as in the dashed line of the Figure; that is, the strength distribution is truncated. If the proof test survivors are affected by the testing conditions then they will not follow the truncated curve and the strength distribution can fall somewhere between the ideal proof test distribution curve and the initial, inert distribution as shown by the dotted line in Figure 3 .

\section{SECTION 111}

\section{Experimental Results}

Proof Testing

The effect of proof testing on the strength distribution at $25^{\circ} \mathrm{C}$ is shown in Figure 4A, B for hot pressed silicon nitride and in Figure $4 \mathrm{C}$ for reaction bonded silicon nitride. As can be seen in these Weibull plots of the data, proof testing truncates the strength distribution for both types of silicon nitride because the breaking strengths of the survivors were greater than the proof stress. This finding indicates that proof testing can be used to eliminate weak specimens and thus improve the structural reliability of silicon nitride in room temperature applications.

However, for turbine applications, proof testing must be able to truncate the high temperature strength distribution to assure component reliability. In principle, the easiest way to obtain such a distribution is to proof test the components at room temperature before using them at high temperature. Then, provided the high temperatures do not affect the flaw distribution, the truncated population formed at room temperature will be truncated also at high temperatures. Alternatively, components must be proof tested at high temperatures. To test these assumptions, sets of specimens from both hot pressed silicon nitride and reaction bonded silicon nitride were proof tested at the 50\% failure probability level at room temperature the survivors were unloaded and then broken at $1200^{\circ} \mathrm{C}$ after $1 / 2$ hour of high 

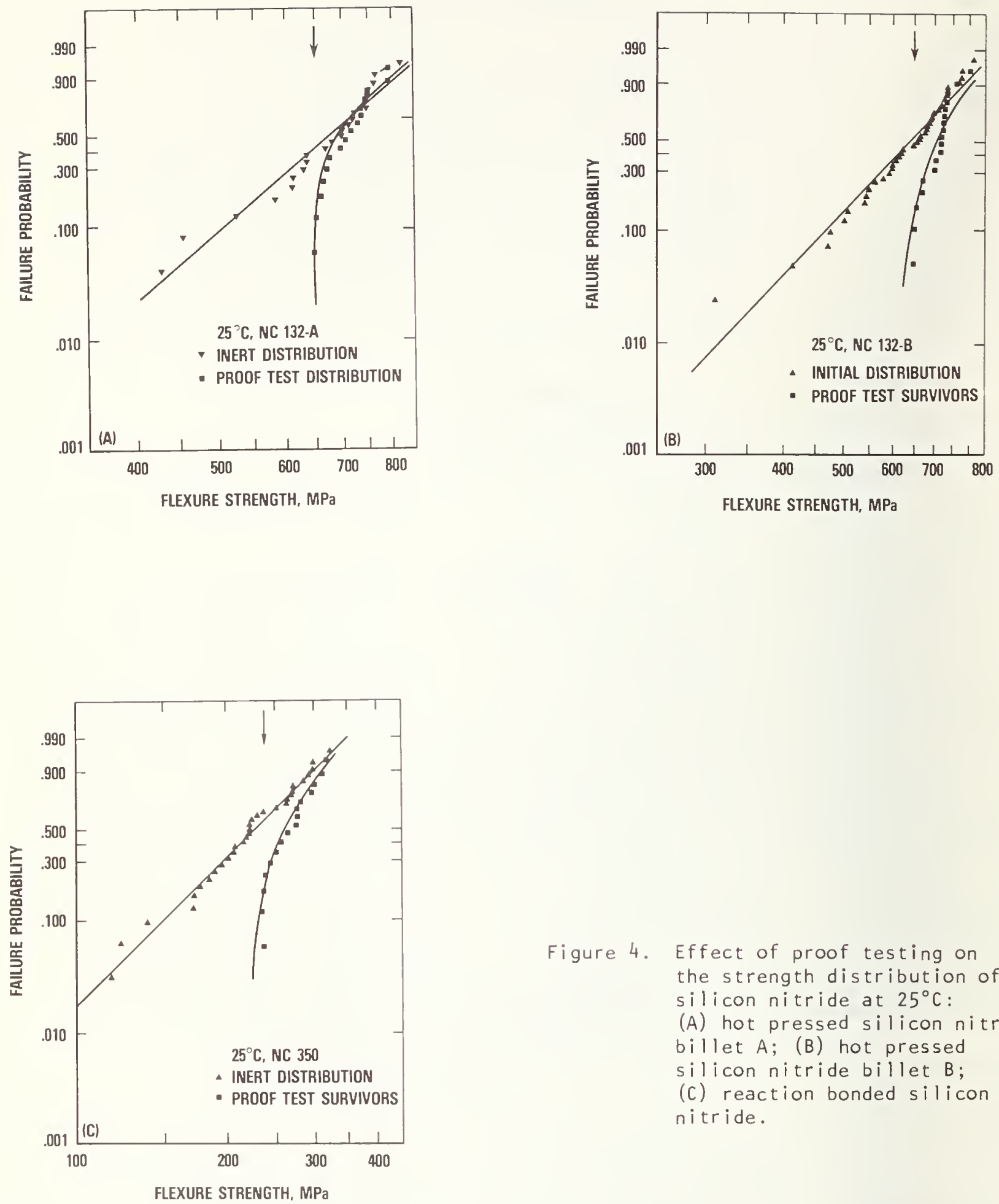

Figure 4. Effect of proof testing on the strength distribution of silicon nitride at $25^{\circ} \mathrm{C}$ :

(A) hot pressed silicon nitride billet $A$; (B) hot pressed silicon nitride billet B; (C) reaction bonded silicon nitride. 
temperature exposure. Another set of hot-pressed specimens was proof tested at $1200^{\circ} \mathrm{C}$ after $1 / 2$ hour at $1200^{\circ} \mathrm{C}$ and the survivors were unloaded and then broken at $1200^{\circ} \mathrm{C}$. The results of this study are shown in Figure 5 . Included in Figure 5 are the initial strength distribution obtained after $1 / 2 \mathrm{hr}$ at $1200^{\circ} \mathrm{C}$, and the theoretically predicted values of the $1200^{\circ}$ strength distribution (the curved lines) after proof testing. We note from this figure that none of the strength distributions determined after proof testing agreed with the theoretical curves. The strength distributions were not truncated because some proof survivors broke below the proof test stress. The Weibull slopes for the proof test survivors are close to those for the initial distribution. It is noteable that as a result of the $1200^{\circ} \mathrm{C}$ exposure, specimens which were broken below the $50 \%$ probability level were weaker than predicted and those broken above the $50 \%$ probability level were stronger than predicted. Further, the $1200^{\circ} \mathrm{C}$ proof test in Figure $5 \mathrm{~B}$ did not truncate the strength distribution much more effectively than the $25^{\circ} \mathrm{C}$ proof test. Thus it appears that the proof test predictions which were based on an inert strength distribution must be modified to account for non-inert service conditions, i.e. a $1200^{\circ} \mathrm{C}$ air environment.

The proof test stress determines the largest flaw that can be present in the region of a specimen that is subjected to the test. As long as this critical flaw is still an effective nucleus for fracture after exposure, the minimum time to failure can be estimated by the proof testing procedure. However, if the critical flaw is modified by

"The predictive strength calculations were done by Sheldon $M$. Wiederhorn using empirical formulations being developed for the reliability of ceramic materials. 

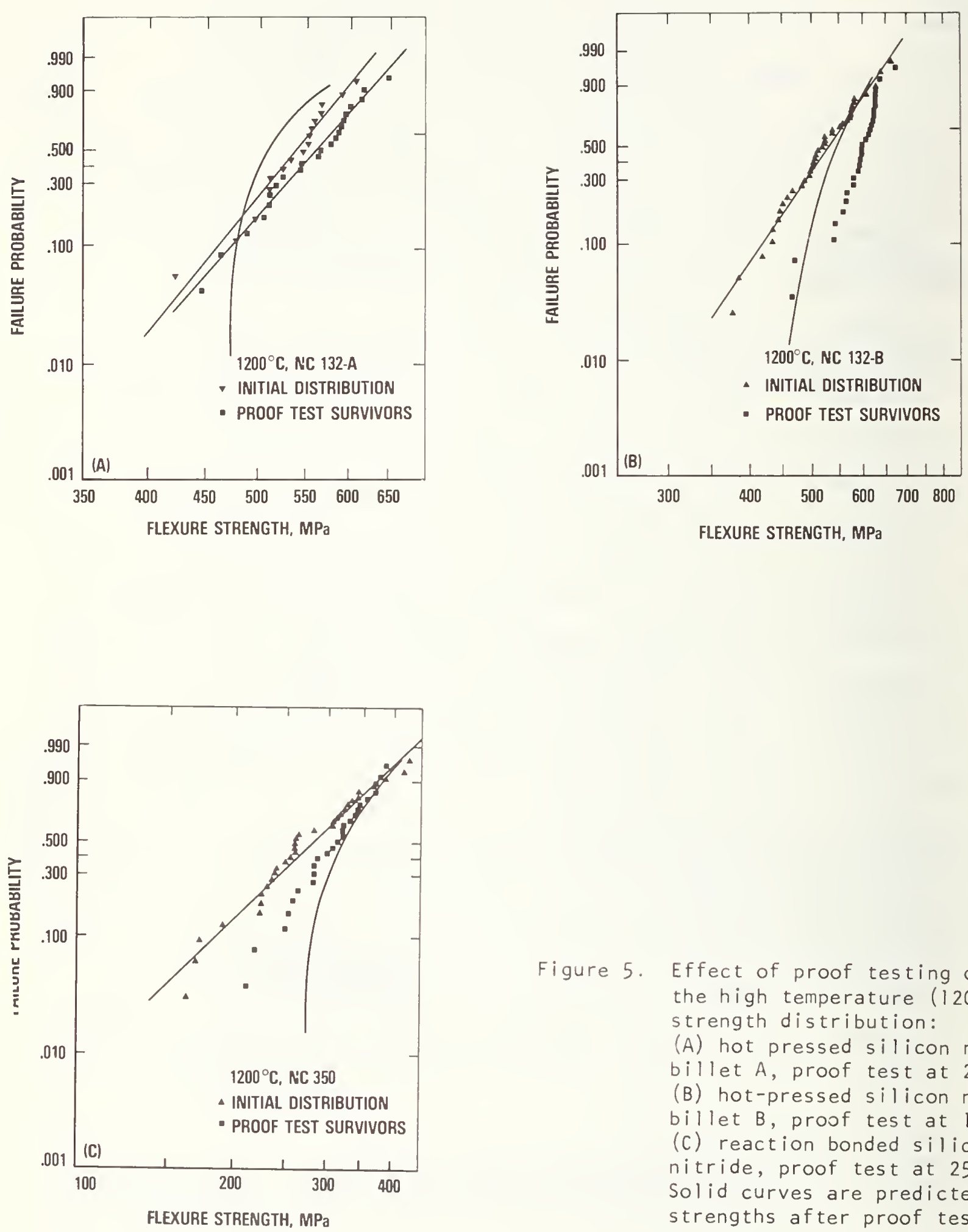

Figure 5. Effect of proof testing on the high temperature $\left(1200^{\circ} \mathrm{C}\right)$ strength distribution:

(A) hot pressed silicon nitride billet $A$, proof test at $25^{\circ} \mathrm{C}$;

(B) hot-pressed silicon nitride billet B, proof test at $1200^{\circ} \mathrm{C}$; (c) reaction bonded silicon nitride, proof test at $25^{\circ} \mathrm{C}$. Solid curves are predicted strengths after proof test. 
the high temperature exposure, then proof testing will not be a viable screening procedure. The results of the tests shown in Figure 5 indicate that specimens behaved differently from theoretical expectations which means that the initial flaw population of the materials was modified by the high temperature exposure. These data show that proof testing will be of doubtful value at the $50 \%$ probability level used to obtain the data.

To test the effect of temperature on the flaw population, a series of exposure experiments was conducted at $1200^{\circ} \mathrm{C}$. Specimens were prooftested before exposure in order to truncate the initial distribution, and other specimens were exposed without proof-testing. Strengths were measured after exposure at room temperature. Figure 6 shows the results
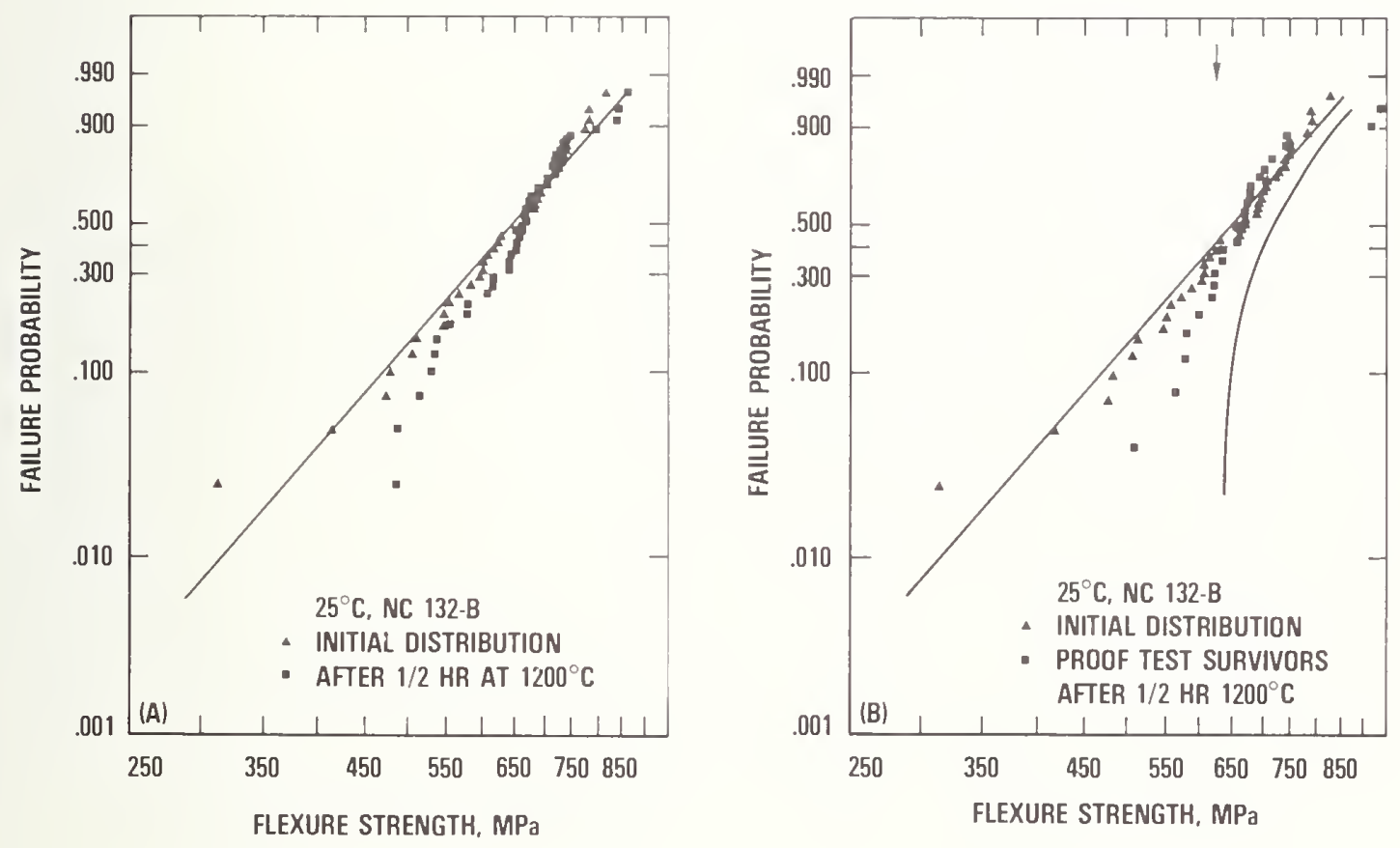

Figure 6. Effect of high temperature exposure on the room temperature strength of hot-pressed silicon nitride, billet B: (A) exposure of as-received specimens; (B) exposure of the survivors of a room temperature proof test. The solid curve in (B) gives the strength distribution after proof testing at room temperature, while the arrow gives the proof test level, $630 \mathrm{MPa}$. 
of a $1 / 2$ hour exposure on the room temperature strength of two sets of specimens from billet $B$, one of which had been truncated prior to exposure. In figure $6 \mathrm{~A}$ we see that the initial, inert distribution was affected by exposure to high temperatures, in that the specimens broke at somewhat higher loads after exposure. In Figure 6B we note the strength distribution after exposure differs from the truncated distribution, which is given in the Figure by the solid curve. Approximately $50 \%$ of the specimens tested broke at loads that were less than the proof-test load. A comparison of Figures $6 \mathrm{~A}$ and $6 \mathrm{~B}$ indicates that after exposure, both the normal and truncated populations gave nearly the same distribution. Thus both populations were altered in such a way that the flaw population after exposure was independent of the initial population. A reasonable explanation for this observation is that the initial population of flaws is replaced by one produced by oxidation at $1200^{\circ} \mathrm{C}$ in air.

To determine whether proof testing is effective in eliminating specimens with large flaws, strength measurements were made on specimens having a flaw that was introduced using a knoop hardness indenter. Strength measurements at room temperature (Table 2) indicated that the indented specimens were comparable to those specimens at the low end of the strength distribution plot, which broke at flaws of the same magnitude i.e. 100-200 um. For proof testing to be useful by eliminating specimens with flaws of this magnitude, it must be demonstrated that such flaws are still fracture nucleation sites after exposure to high remperatures. Strength measurements on indenied specimens after exposure to $1200^{\circ} \mathrm{C}$ for 100 hours indicated that $N C 132$ billet B, the NCX34 billet, and the NC350 billets fractured from the site of the indentation, Table 2. Thus the artifically introduced flaws were still effective nucleation sites in these materials and proof testing could be used to truncate the 


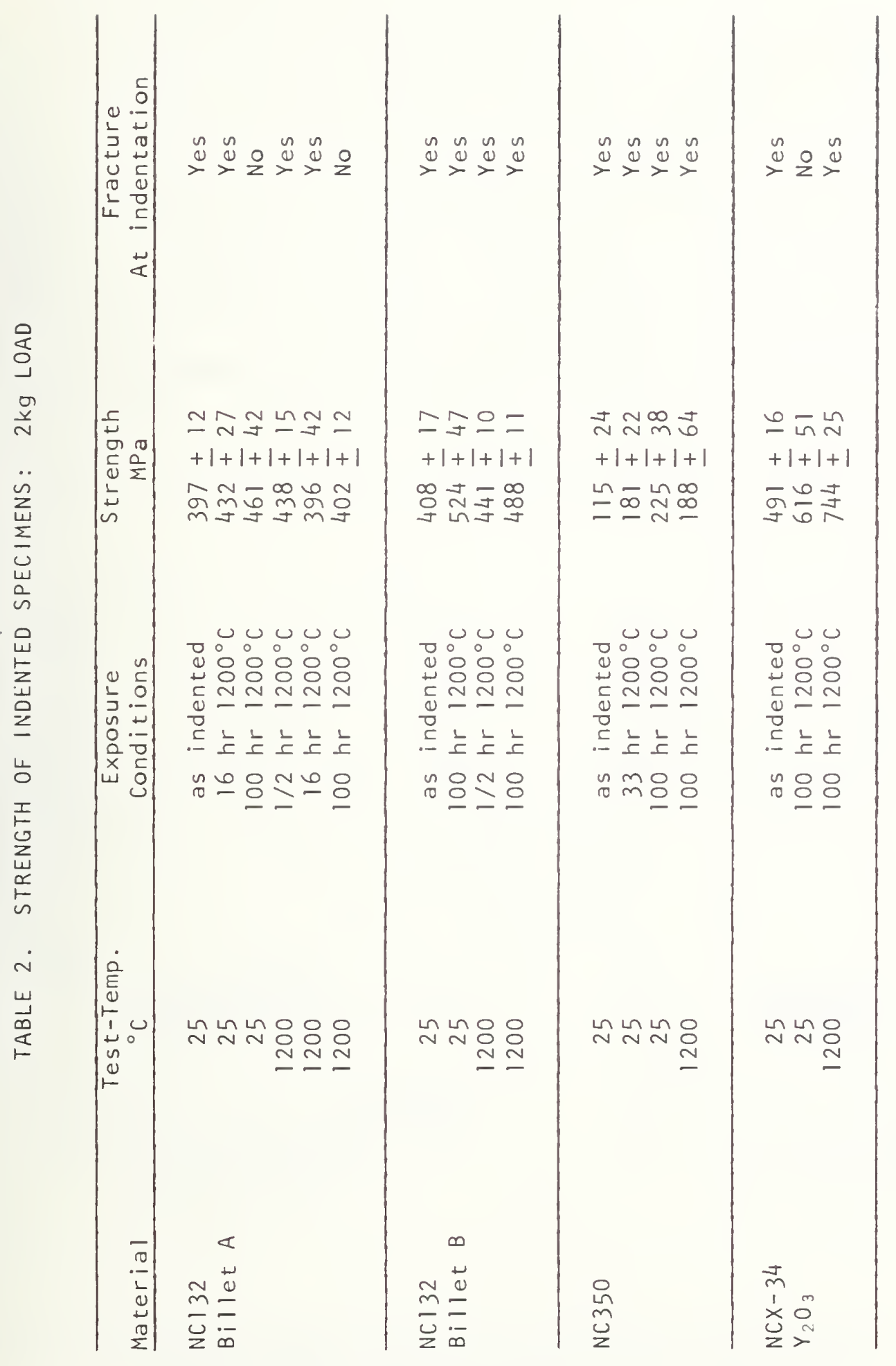


strength distribution by eliminating large flaws. By contrast, specimens from NCl32 billet A failed from origins that were not located at the site of the indentation, which indicates that proof testing would be of little value for billet $A$ because specimens would be eliminated unnecessarily. The indentations were in fact removed during the oxidation .

The findings obtained in the indentation studies were confirmed in strength studies conducted on specimens that were not indented. Strength measurements on billet $\mathrm{A}$ after 100 hours of exposure at $1200^{\circ} \mathrm{C}$ indicated that the strength at $25^{\circ} \mathrm{C}$ and $1200^{\circ} \mathrm{C}$ decreased and the strengths were considerably below the initial (as ground) strengths shown in Figure 7 . Thus, flaws generated by high temperature oxidation are far more severe
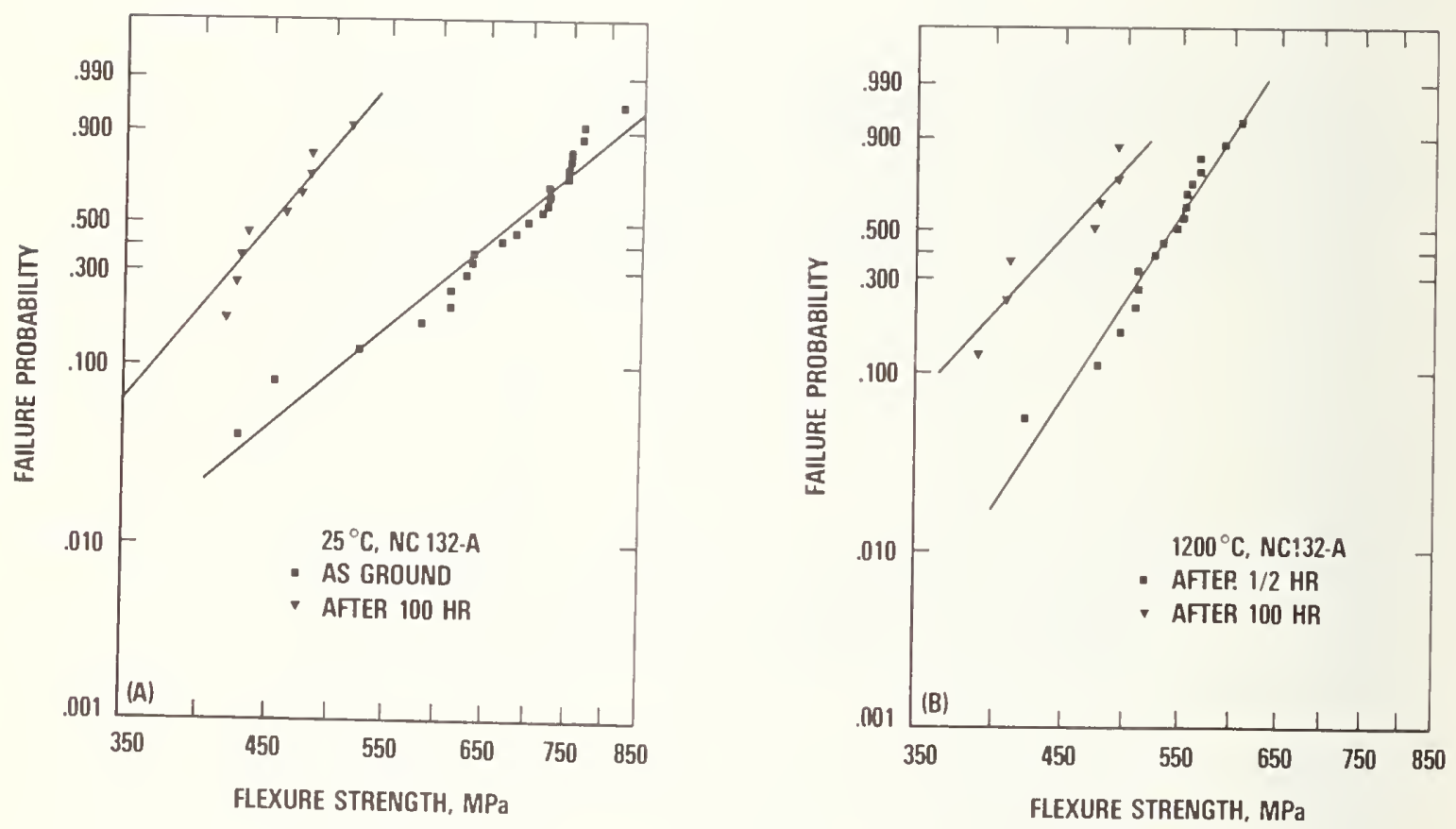

Figure 7. Effect of high temperature exposure in air for $100 \mathrm{hr}$ on the strength of hot-pressed silicon nitride (billet $A$ ): (A) strength at $25^{\circ} \mathrm{C}$; (B) strength at $1200^{\circ} \mathrm{C}$. 
than the machining flaws originally present in these specimens. The

flaws also are more severe than the large cracks introduced by indentation.

The strength of the $\mathrm{Y}_{2} \mathrm{O}_{3}$ doped silicon nitride (NCX34) also degraded after exposure at $1200^{\circ} \mathrm{C}$. The data plotted in Figure 8 show that the mean strength at $25^{\circ} \mathrm{C}$ decreased after 100 hours exposure from $880 \mathrm{MPa}$ to $692 \mathrm{MPa}$ and the Weibull slope decreased from 16.3 to 5.9. This $20 \%$ decrease in strength was significantly greater than that observed for billet $A$. The indentation results in Table l show that the indentation was still the effective flaw after $100 \mathrm{hr}$ at $1200^{\circ} \mathrm{C}$ but was not the effective flaw in specimens broken at $25^{\circ} \mathrm{C}$ after the same exposure.
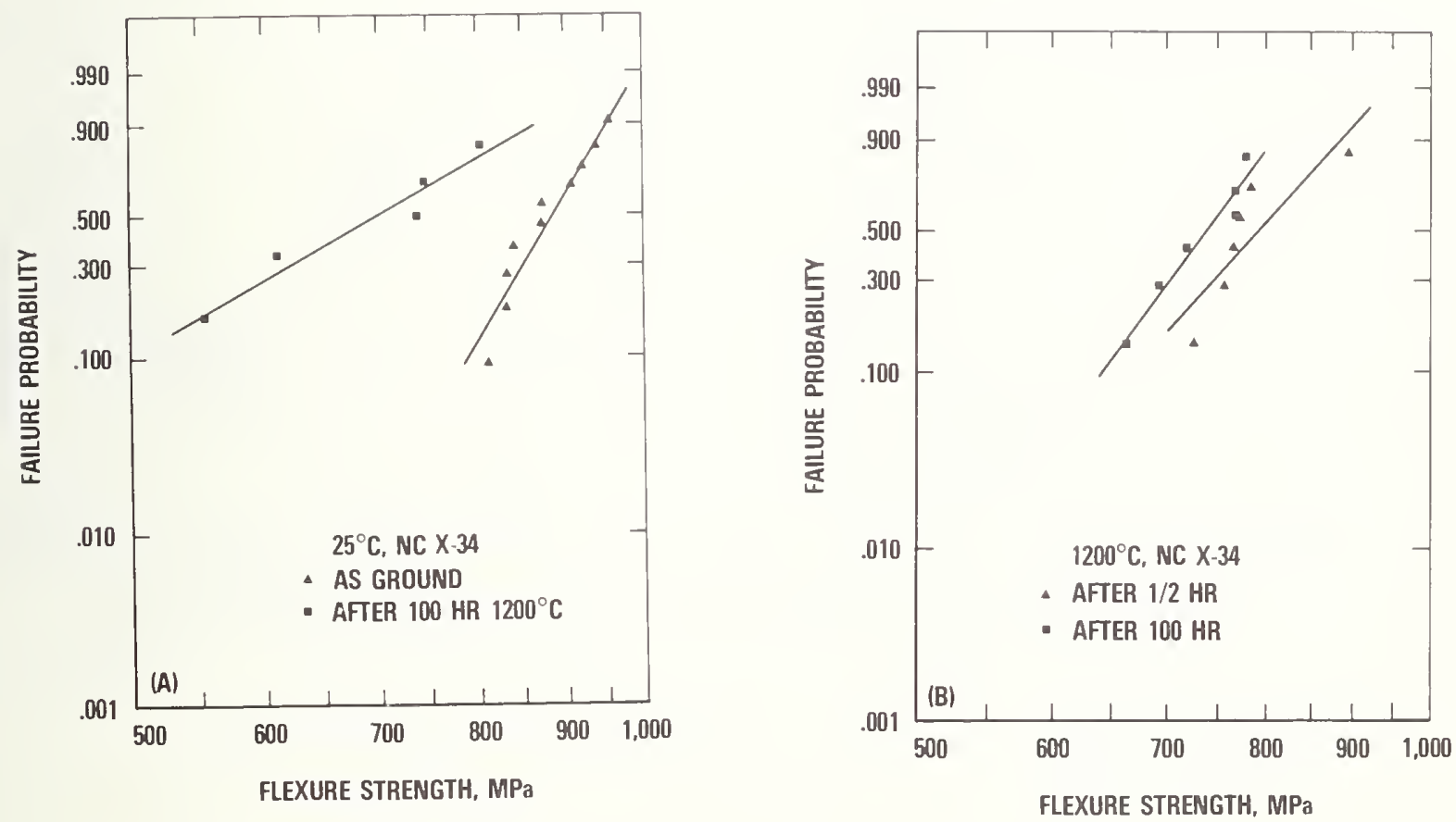

Figure 8. Effect of high temperature exposure for $100 \mathrm{hr}$ on the strength of $\mathrm{Y}_{2} \mathrm{O}_{3}$ doped silicon nitride: (A) strength at $25^{\circ} \mathrm{C}$; (B) strength at $1200^{\circ} \mathrm{C}$. 
The strength behavior of NCl32 billet B differs from that obtained on billet $\mathrm{A}$. Strength measurements at $25^{\circ} \mathrm{C}$ after 100 hours of exposure to $1200^{\circ} \mathrm{C}$, Figure $9 \mathrm{a}$, indicate that the mean strength decreased from 640 MPa to $580 \mathrm{MPa}$, whereas the Weibull slope increased from 5.9 to 14.4 . The net effect of the increase in the Weibull slope is to increase the strength of specimens that fail at low levels of failure probability, which means that large strength impairing flaws are not generated in billet $B$ by high temperature exposure. As a consequence of this behavior,
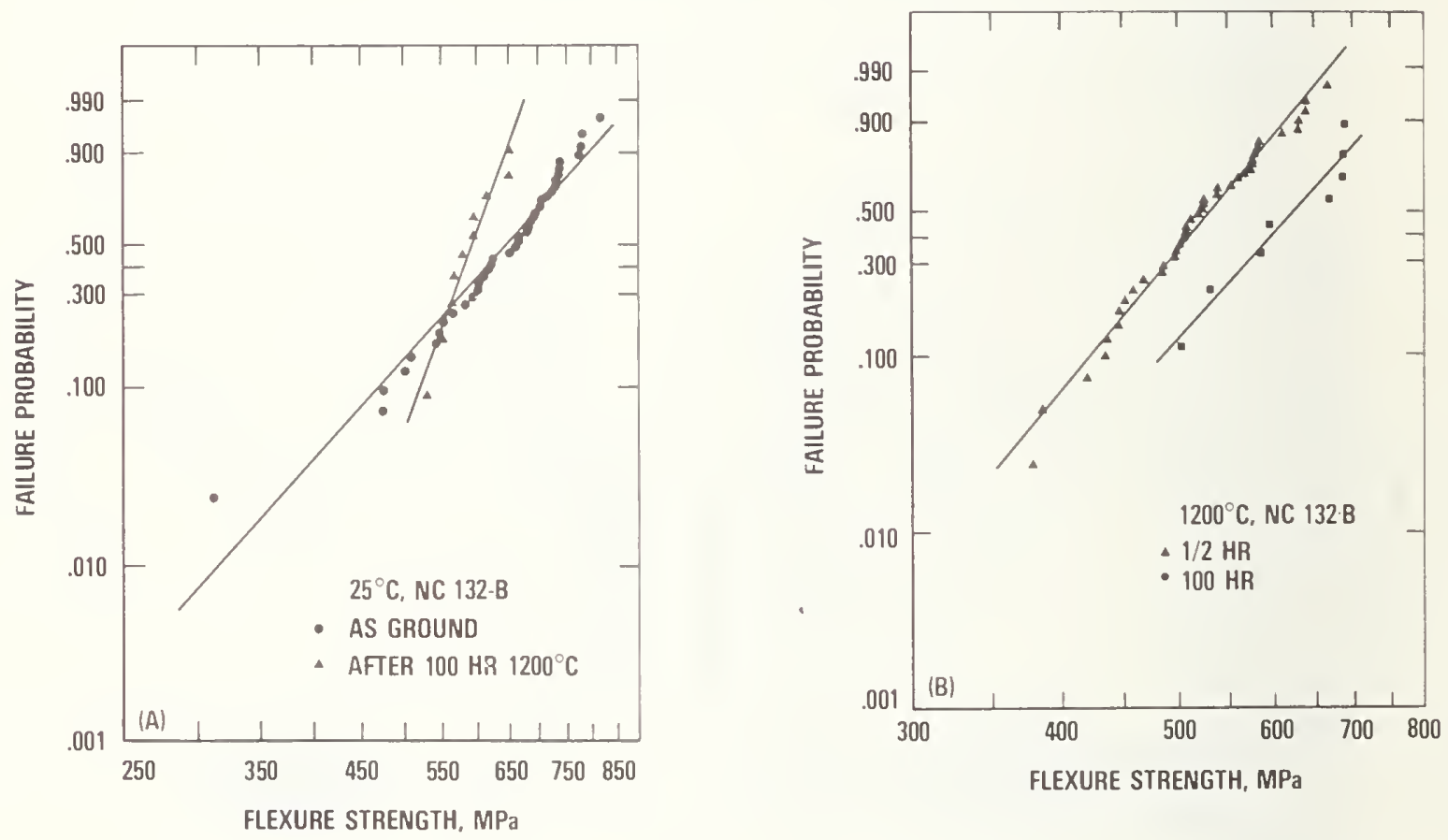

Figure 9. Effect of high temperature exposure for $100 \mathrm{hr}$ on the strength of hot-pressed silicon nitride (billet $B$ ):

(A) strength at $25^{\circ} \mathrm{C}$; (B) strength at $1200^{\circ} \mathrm{C}$. 
components that contain large flaws can be eliminated by proof testing without fear that new, more serious flaws will be generated by high temperature oxidation. This conclusion is supported by the data obtained at $1200^{\circ} \mathrm{C}$ after 100 hours of exposure at $1200^{\circ} \mathrm{C}$. For this condition of testing, the measured strengths (figure 7b) were greater than those obtained after $1 / 2$ hour of exposure at $1200^{\circ} \mathrm{C}$. Therefore the natural flaws generated by high temperature exposure are less severe than those that were introduced by indentation, and as a consequence, proof testing can be used to truncate the strength distribution by eliminating large flaws that might be present in the specimen. We note from Figure 10 and Table 2 that the data on the reaction bonded billets were qualitatively
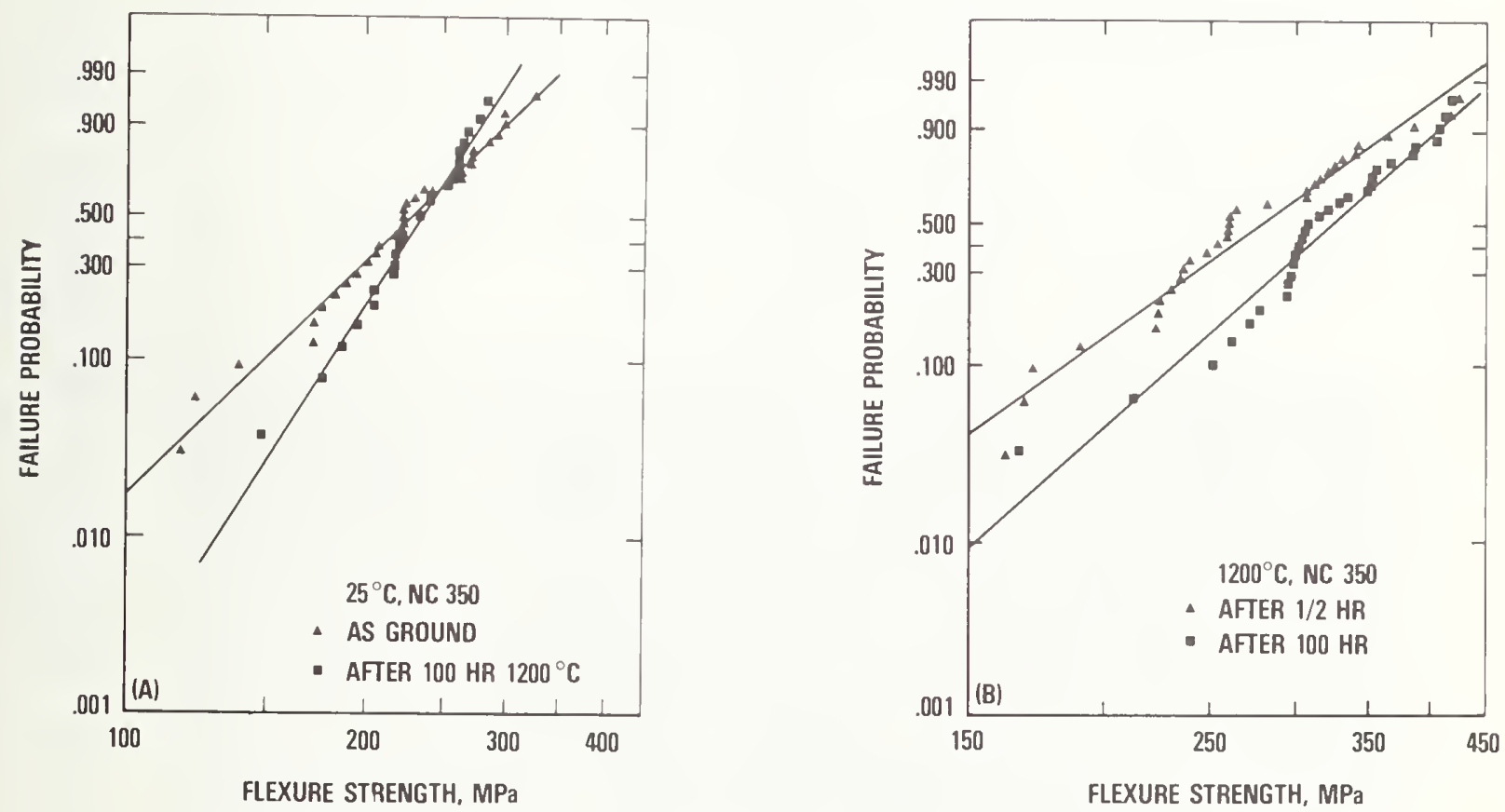

Figure 10. Effect of high temperature on the strength of reaction bonded silicon nitride; $100 \mathrm{hrs}$ at $1200^{\circ} \mathrm{C}$ : (A) strength at $25^{\circ} \mathrm{C}$; (B) strength at $1200^{\circ} \mathrm{C}$. 
the same as for those obtained on billet B; that is oxidation improved the strength by healing or otherwise reducing the size of large flaws. Therefore, it is concluded that proof testing can be used to improve the performance of components made from reaction bonded material.

\section{Flaw Healing and Generation}

To determine the reason for strength changes in hot pressed silicon nitride, a study of the oxidized surfaces and of the fracture surfaces was conducted using light microscopy, scanning electron microscopy and transmission electron microscopy. Light micrographs shown in Figure 11 present a time sequence of surface oxidation of hot pressed silicon nitride billet $B$. This time sequence corresponds with the strength

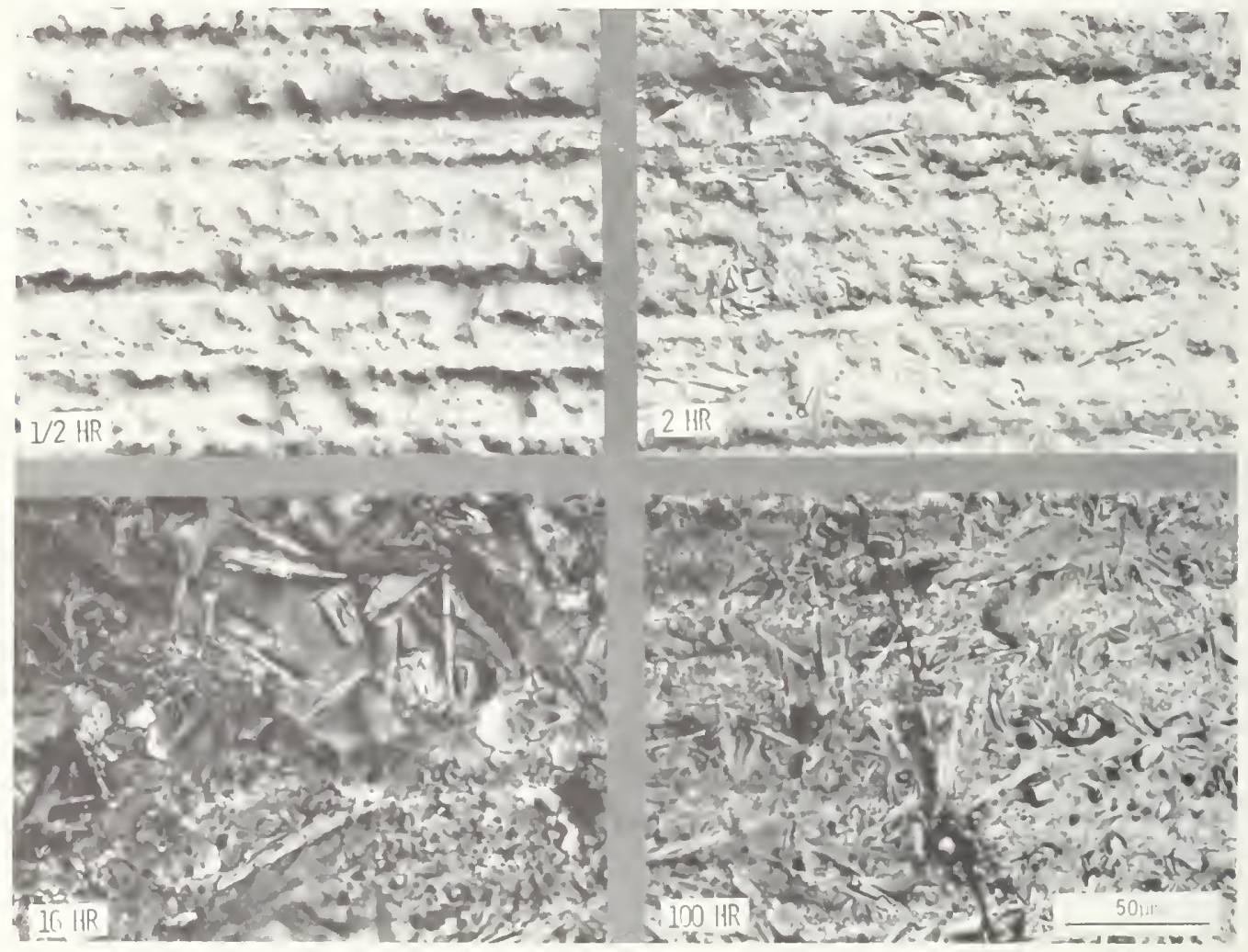

Figure 11. Effect of exposure at $1200^{\circ} \mathrm{C}$ on the surface structure of hot-pressed silicon nitride: (a) $1 / 2$ hour exposure; (b) 2 hour exposure; (c) 16 hour exposure; (d) 100 hour exposure. 
measurements shown in Figure 12. As can be seen from Figure 11 , the surface texture changed with time as the oxides formed and after 16 hours the grinding marks were no longer visible. Oxide filled the grinding grooves after $1 / 2$ hour, distinct platelets were seen after 2 hours of oxidation and by the time the components were oxidized for 64 and 100 hours, the specimen was covered with a thick polycrystalline oxide. The oxide film formed on both billet $A$ and billet $B$ specimens after 100 hr exposure had a glassy appearance and had a dispersion over the surface of smooth and uneven mounds and pits, 50-100 um in diameter.

$X$-ray diffraction studies indicated that silicon oxynitride $\left[\mathrm{Si}_{2} \mathrm{~N}_{2} \mathrm{O}\right]$ formed within the scale after $1 / 2$ hours of exposure. While after 100 hours of exposure enstatite $\left[\mathrm{MgSiO}_{3}\right], \mathrm{B}$ cristobalite $\left[\mathrm{B}-\mathrm{SiO}_{2}\right]$ and silicon oxynitride were found. Transmission electron microscopy studies of oxide scales demonstrated that at least two amorphous phases (probably magnesium silicate and silica glasses) can occur within the oxide [21]. The light microscopy and transmission electron microscopy studies showed that the silicon oxynitride was located at the silicon nitride-oxide interface and can be amorphous or crystalline whereas the silicate glasses and other crystalline materials were located toward the oxide-air interface $[14,21]$.

The chemical composition of the oxide scale and the mounds and the pits that formed in this scale were evaluated by means of a scanning electron microscope with elemental analysis capability. Specimens that were exposed for 100 hours contained silicon, magnesium, calcium, iron and manganese in the oxide. Since these last four elements are the major impurities of the magnesium doped silicon nitride, their presence 

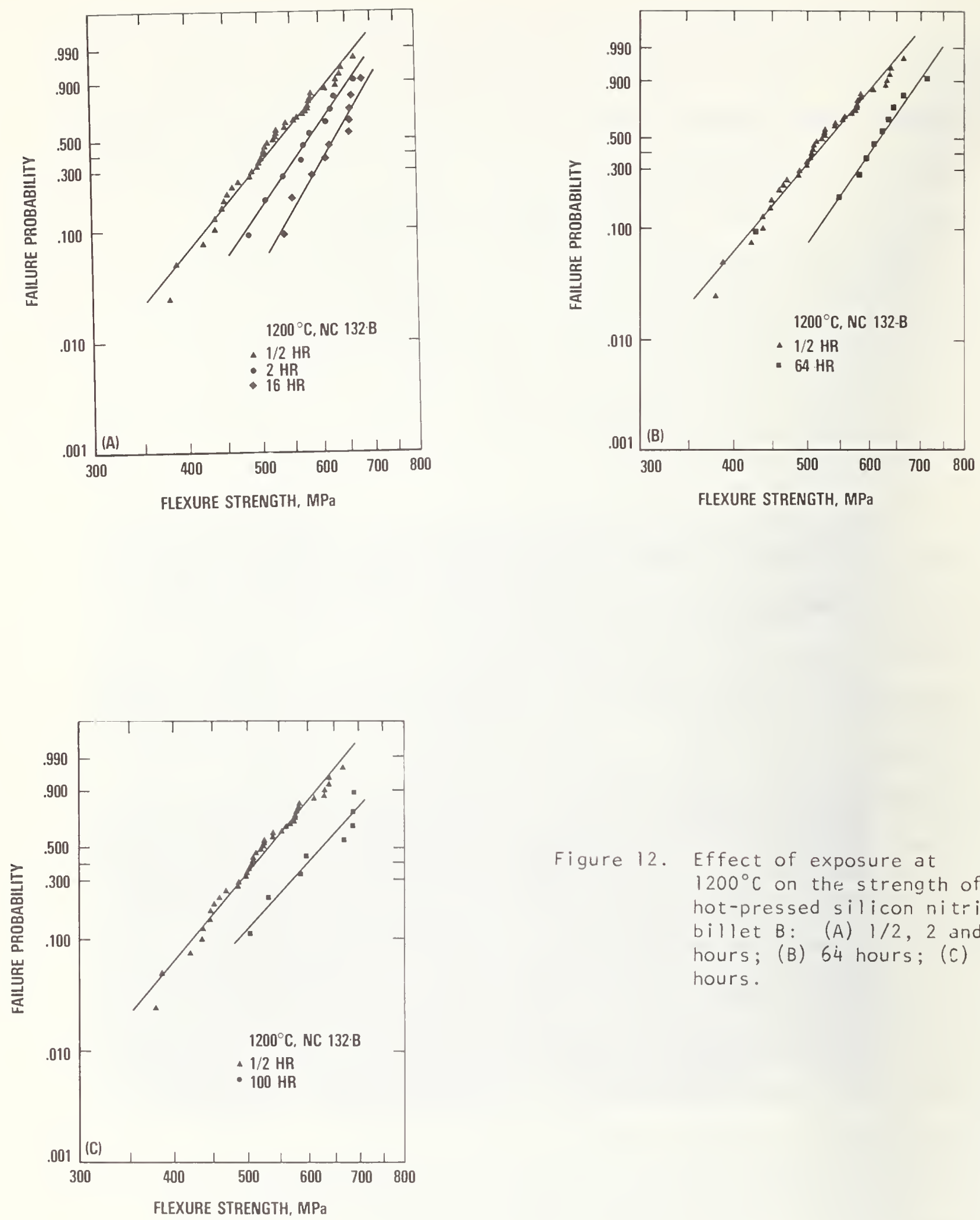

Figure 12. Effect of exposure at $1200^{\circ} \mathrm{C}$ on the strength of hot-pressed silicon nitride, billet B: (A) $1 / 2,2$ and 16 hours; (B) 64 hours; (C) lor hours. 
in the oxide suggests diffusion of some of the impurities from the body of the ceramic to the oxide layer during oxidation. The surface mounds and pits found in billet A contained only the silicon and iron, and hence differed in composition from the remainder of the oxide scale as seen in Figure 13. By contrast, the mounds and pits in billet $B$ were approximately the same composition as the oxide scale.

When the oxide scale was removed from NC132 specimens oxidized 100 hrs at $1200^{\circ} \mathrm{C}$ (by etching in $\mathrm{Hf}^{\circ} \mathrm{H}_{2} \mathrm{SO}_{4}$ ) the silicon nitride surface was

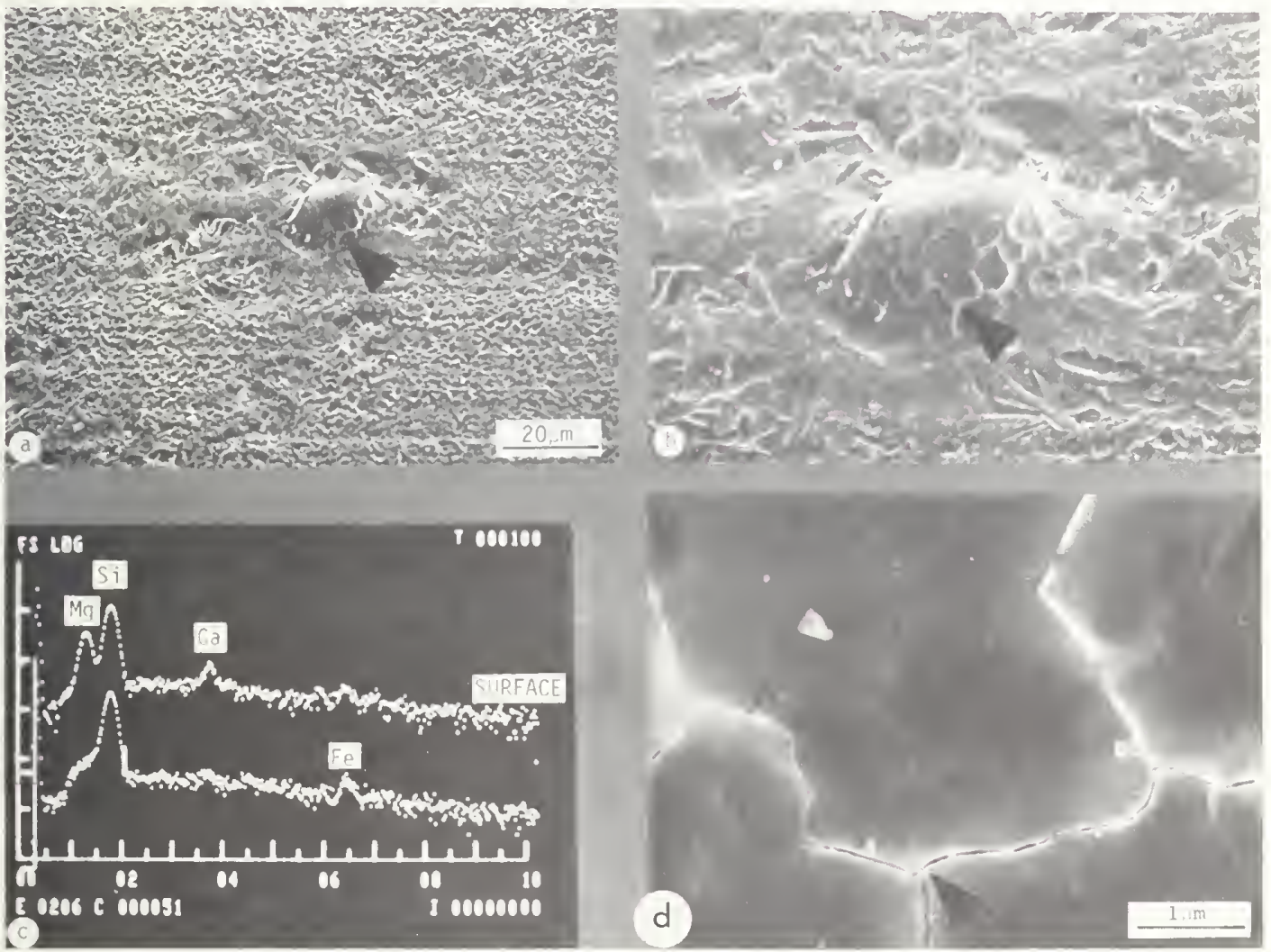

Figure 13. Scanning electron microscopic examination of a pit formed during exposure at $1200^{\circ} \mathrm{C}$ for 100 hours: (a,b) low magnification photographs; (c) X-ray element analysis of the pit and the nearby surface; (d) details of the cracks on the surface. $\boldsymbol{\Delta}$ indicates same area in $a, b$ and $d$. 
found to be heavily pitted. The pits were $\sim 50 \mu \mathrm{m}$ in diameter and occurred over all surfaces. By comparing etched and unetched fracture interfaces, it was evident that fracture originated at the surface pits as shown in Figure 14. Specimens from Billet A were more heavily pitted than those from Billet B. Examination of polished cross-sections of the specimens also showed penetration of the oxide into the silicon-nitride along pits as well as along cracks.

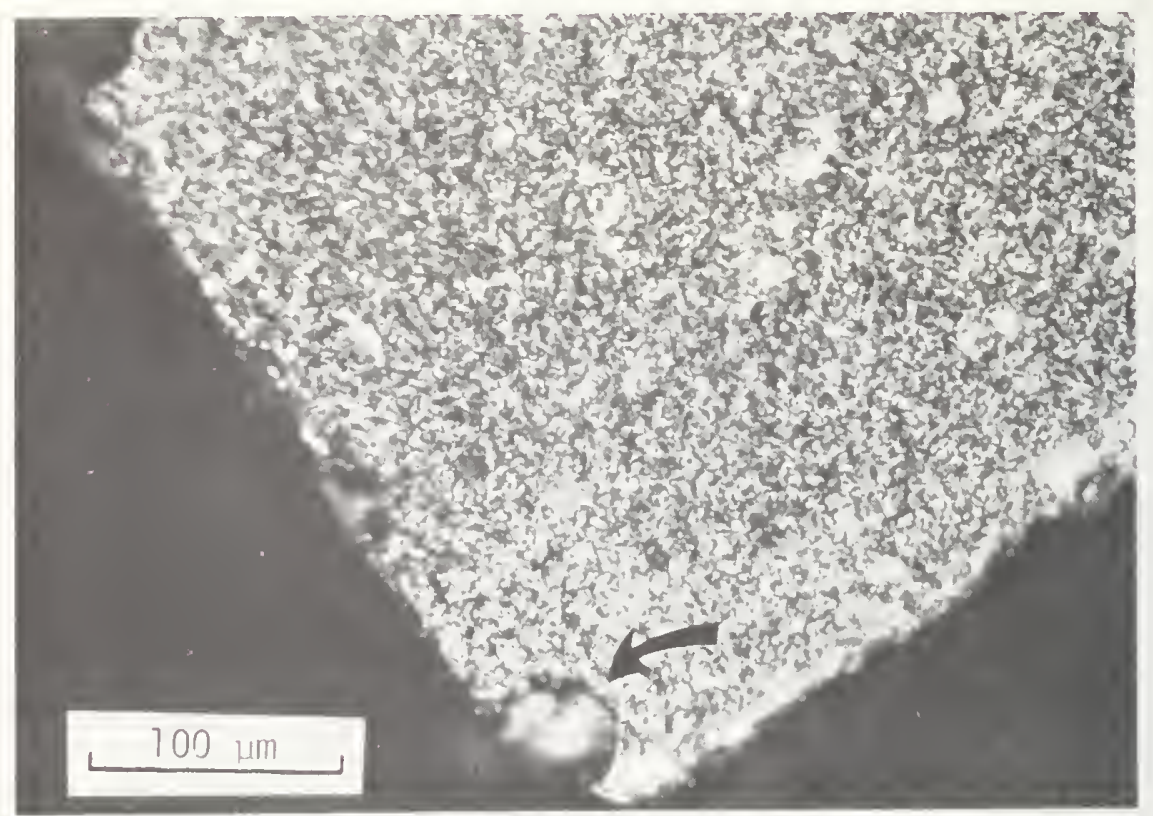

Figure 14. Pit as a fracture source in hot-pressed silicon nitride. The specimen was broken after exposure of 100 hrs at $1200^{\circ} \mathrm{C}$. The surface oxide was removed by etching.

Pits appeared to form under some of the mounds that were observed in the oxide scale. Some mounds have a glassy appearance and as shown in Figure 15, sometimes contained a hole in them. By focusing through these holes [using light microscopy], pits approximately 50 um in diameter were observed beneath the mounds. The appearance and structure of some mounds suggest that a liquid phase was present at the site of the pit during oxidation. When the indented specimens were examined after 100 
hr exposure it was found that the indentations were smaller in Billet B and completely gone in Billet $A$. Thus the oxidation process had reduced the effectiveness of the indentation in these specimens and had created new flaws in the form of surface pits.

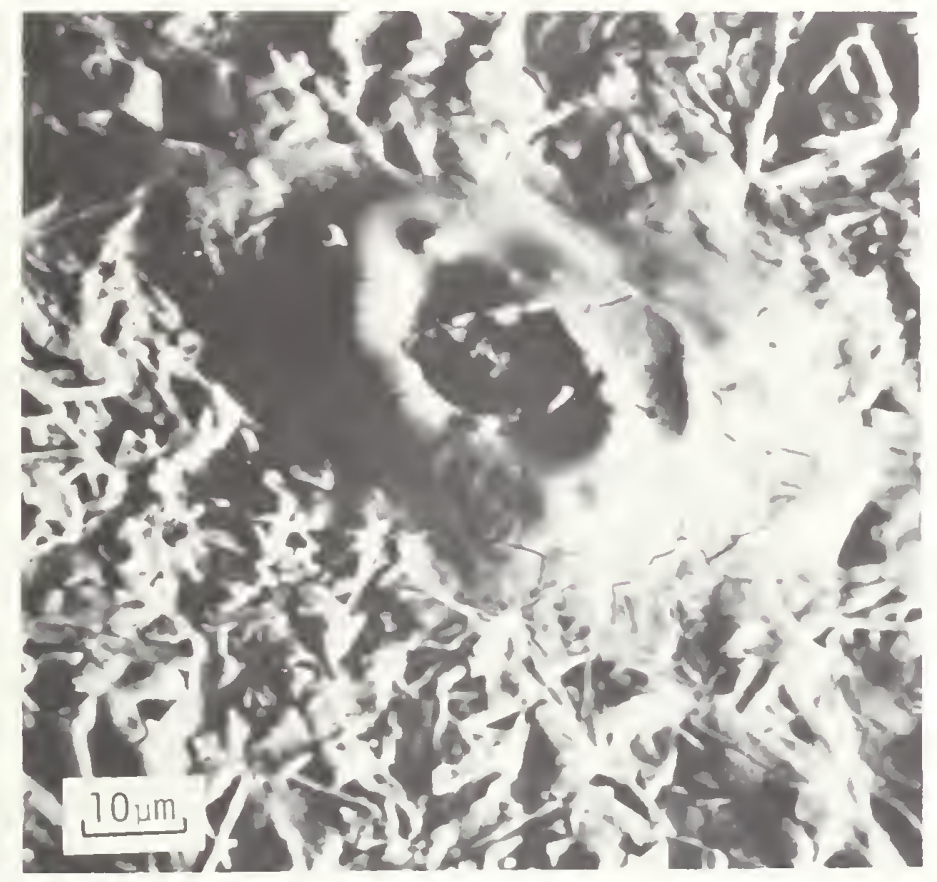

Figure 15. Mound formed during exposure of hot-pressed silicon nitride, billet B, for 100 hrs. at $1200^{\circ} \mathrm{C}$. The hole in the center of the mound suggests that gas had issued forth from the mound.

These microscopy studies on $\mathrm{NCl} 32$ show that the oxidation is a complex process which involves mass transport of impurities from the matrix, nucleation and growth of new phases within the oxide scale, penetration of the silicon nitride interface along cracks and surface and subsurface inclusions. The diagram in Figure 16 illustrates the interaction observed between the oxide scale and flaws. Two flaws 
are indicated: a crack and a subsurface inclusion or pore. Because the oxide scale grows into the matrix, the original, silicon nitride surface

EFFECT OF OXIDATION ON

FLAWS IN $\mathrm{Si}_{3} \mathrm{~N}_{4}$
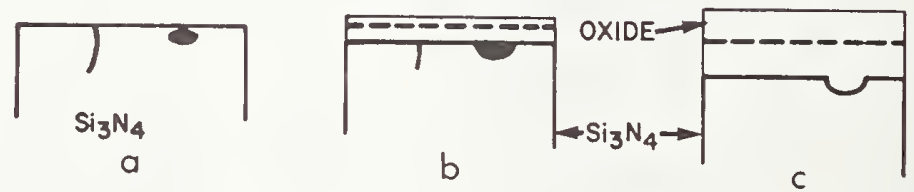

Figure 16. Effect of exposure at $1200^{\circ} \mathrm{C}$ on flaws in silicon nitride: (a) surface crack and subsurface inclusion before exposure; (b) after exposure crack size is reduced and subsurface flaw has reacted with the oxide; (c) oxide growth has removed the surface crack and enlarged the subsurface flaw to produce a pit in the silicon nitride.

as indicated by the dotted 1 ine recedes. The crack is reduced in size and the inclusion or pore interacts with the oxide. If the oxidation continues long enough the crack is removed completely as in (c) and the inclusion or pore is replaced completely by oxide. The severity of the oxidation reaction varies with the material. The effect of the oxide scale on strength degradation can be related to the form of the oxidation process for each material. 
0xidation is less severe for reaction bonded (NC350) and for yttriadoped silicon nitride (NCX34) specimens than for the magnesia doped (NC132) materials. An oxide film approximately 10 microns thick formed on the reaction bonded specimens that were oxidized for 100 hours. The x-ray powder diffraction patterns from the 100 hour specimens and $1 / 2$ hour specimens showed that the primary crystalline phase was a-cristobalite. This silica film appeared to be continuous over the surface. The hardness indentations were visible both before and after acid removal of the oxide film. The initial porosity of the material makes it difficult to distinguish additional oxide related pitting. The continuous oxide film has a strengthening effect on the machined test specimens because it forms a protective surface layer and fills or heals cracks.

After 100 hours of exposure the oxide film on $\mathrm{Y}_{2} \mathrm{O}_{3}$ doped silicon nitride specimens was approximately 20 um thick. The X-ray diffraction patterns of the oxide layers showed that $\mathrm{Y}_{2} \mathrm{Si}_{2} \mathrm{O}_{7}$ and $\alpha-\mathrm{SiO}_{2}$ were the primary crystalline phases. When the oxide was removed by etching, the silicon nitride surface showed traces of the machining grooves and had shallow pits. The absence of deep pits at fracture interfaces indicates that the strength degradation could not be attributed to the oxide pit formation as found in $\mathrm{NCl} 32$ and is more likely related to exposure induced internal oxidation and phase changes in the intergrain phase.

SECTION IV

\section{Discussion of Results}

Evaluation of Proof Tests

The results of this study indicate that there are limits to the application of proof testing as a method of assuring the lona term reliability of silicon nitride in turbine applications. Proof testing is 
of value only if the flaws eliminated during the proof test are in fact the flaws that will cause failure during service. Modification of the flaw population by oxidation can invalidate a proof test procedure, either by eliminating the machining flaws that cause failure at room temperature, or, by changing their severity. In the present study, it was shown that high temperature exposure $\left[1200^{\circ} \mathrm{C}\right]$ modifies the flaw population sufficiently so that truncation of the strength distribution of machined specimens is no longer observed after exposure times as short as $1 / 2$ hour. Therefore, although the effects of the flaws that result from machining operations can be reduced by proof testing, this truncation of the strength distribution will serve little practical value if those machining flaws probably are not the ones that cause failure after high temperature exposure. From these results it is apparent that there is an upper bound to the proof test load above which no positive benefits can be gained by proof testing. This upper-bound proof test load depends on the material and on the condition of use. Subjecting components to loads in excess of the upper-bound proof test level will merely break an excessive number of components and will not limit the maximum size of a flaw that can be present during service without causing failure.

The maximum proof test load for a given application can be determined when an artifical flaw of known size is introduced into a test specimen and is still effective as a crack origin after high temperature exposure. In the present study, such flaws were introduced by hardness indentations. The results of the surface indentation studies for the reaction bonded silicon nitride show that bend specimens broke at the indentations after 100 hours of exposure. Since these specimens would have been broken by a load of $115 \mathrm{MPa}$ prior to high temperature exposure, the 
results indicate that a proof load of $115 \mathrm{MPa}$ would have truncated the strength distribution of the population. In the proof test conducted on reaction bonded silicon nitride, however, it was shown that a load of $225 \mathrm{MPa}$ broke $45 \%$ of the specimens but did not result in truncation of the strength distribution. From these two results we conclude that the maximum proof test load for the reaction bonded material should be between $115 \mathrm{MPa}$ and $225 \mathrm{MPa}$.

The strength studies on the hot pressed silicon nitride also can be used to obtain an estimate of the maximum proof test stress for this material. Indentations in billet $B$, which reduced the strength to approximately $400 \mathrm{MPa}$, were effective flaw nucleation sites after 100 hours of exposure at $1200^{\circ} \mathrm{C}$. However, a $630 \mathrm{MPa}$ proof test on this billet did not result in a truncated population at high temperatures. From these results we conclude that the maximum proof test load for billet B lies somewhere between 400 and $630 \mathrm{MPa}$. In contrast with this finding on billet $B$, results on billet $A$ indicate that the maximum effective load for proof testing must be less than $400 \mathrm{MPa}$, since the indentations in specimens from this billet were not effective nucleation sites after high temperature exposure. Therefore, proof testing would be more effective in truncating the strength distribution of billet $B$ specimens than billet A specimens. The limited results obtained for yttria-doped, material showed that indentations were effective flaw nucleation sites for specimens that were broken at $1200^{\circ} \mathrm{C}$ after 100 hours without cooling but not for specimems that were cooled to room temperature before breaking. The indentations reduced the inert strength to $2490 \mathrm{MPa}$, which indicates that the maximum effective proof test load should be less than $490 \mathrm{MPa}$. The cause of the large strength loss which 
occurs when this material is cooled from $1200^{\circ} \mathrm{C}$ to room temperature before testing is more likely related to microstructural changes than to the oxide-flaw interactions that produced the pits in Figure 15 .

\section{Effects of Oxidation on Flaws}

It is apparent from the results that the oxidation which occurs during exposure at $1200^{\circ} \mathrm{C}$ has a significant effect on the strength distribution. The flaw population which controls the strength can be changed in the manner shown in Figure 16. Two types of flaw are considered in Figure 16a, a crack at the surface and an internal flaw which can be an inclusion, a large pore or a crack. When oxidation occurs the crack interfaces oxidize at least as fast as the ground surface and the crack can be blunted. The oxide interface grows into the silicon nitride matrix, removes surface imperfections, and reduces the size of cracks. Internal inclusions can oxidize and change their volume and composition. The mounds in the oxide and pits in the matrix, shown in Figures 14 and 15 respectively, are equivalent to $\sim 50$ grain diameters. The accelerated oxidation in areas this size could be related to a concentration of impurities in a mass of incompletely sintered grains or to the rapid oxidation of large tungsten-based inclusions. Such reactions produce an oxide filled pit in the matrix. Until the microstructure is examined more closely, the mode of pit formation cannot be described completely. These oxidation or corrosion pits act as strength limiting flaws in specimens exposed for long times. It is therefore essential to determine why they form and how to control their formation. 
The effects of exposure at $1200^{\circ} \mathrm{C}$ on the strength distributions of the four batches of silicon nitride are summarized in Figure 17 and 18 . In these figures, it can be seen that the $25^{\circ} \mathrm{C}$ and the $1200^{\circ} \mathrm{C}$ strengths of reaction bonded material and billet $\mathrm{B}$ of $\mathrm{NC}-132$ are increased by exposure at $1200^{\circ} \mathrm{C}$ whereas the strengths of the $\mathrm{Y}_{2} \mathrm{O}_{3}$ doped-material (NCX-34) and billet $\mathrm{A}$ of $\mathrm{NC}-132$ are decreased. These differences are statistically significant and are related to the interaction between the oxide formation and the material. The microstructural differences between the 3 hotpressed materials are related to the composition. The specific interactions could not be pursued during the present program but should be investigated in order to identify the specific cause of the degradation and to guide further development of materials.

\section{Suggestions for Future Programs}

The effects of exposure on the strength of silicon nitride are related to compositional variations in the materials. In the present program the exposure was 1 imited to $1200^{\circ} \mathrm{C}$ in air for a maximum of 100 hours. The effects of longer exposure and different temperatures on strength must be documented. It will be necessary also to test these materials in the service atmosphere. The proof-test procedures for lifetime predictions must be modified to account for the change in flaw population with exposure. An evaluation of the strength distribution under static load will be necessary. In order to investigate the effect of exposure on a wide range of flaw sizes and flaw size distributions, specimens should be tested with known flaw sizes such as those introduced with a Knoop indenter. Extensive microstructural analysis should be carried out on the test specimens as well as on materials prepared with known compositional and structural variations. 

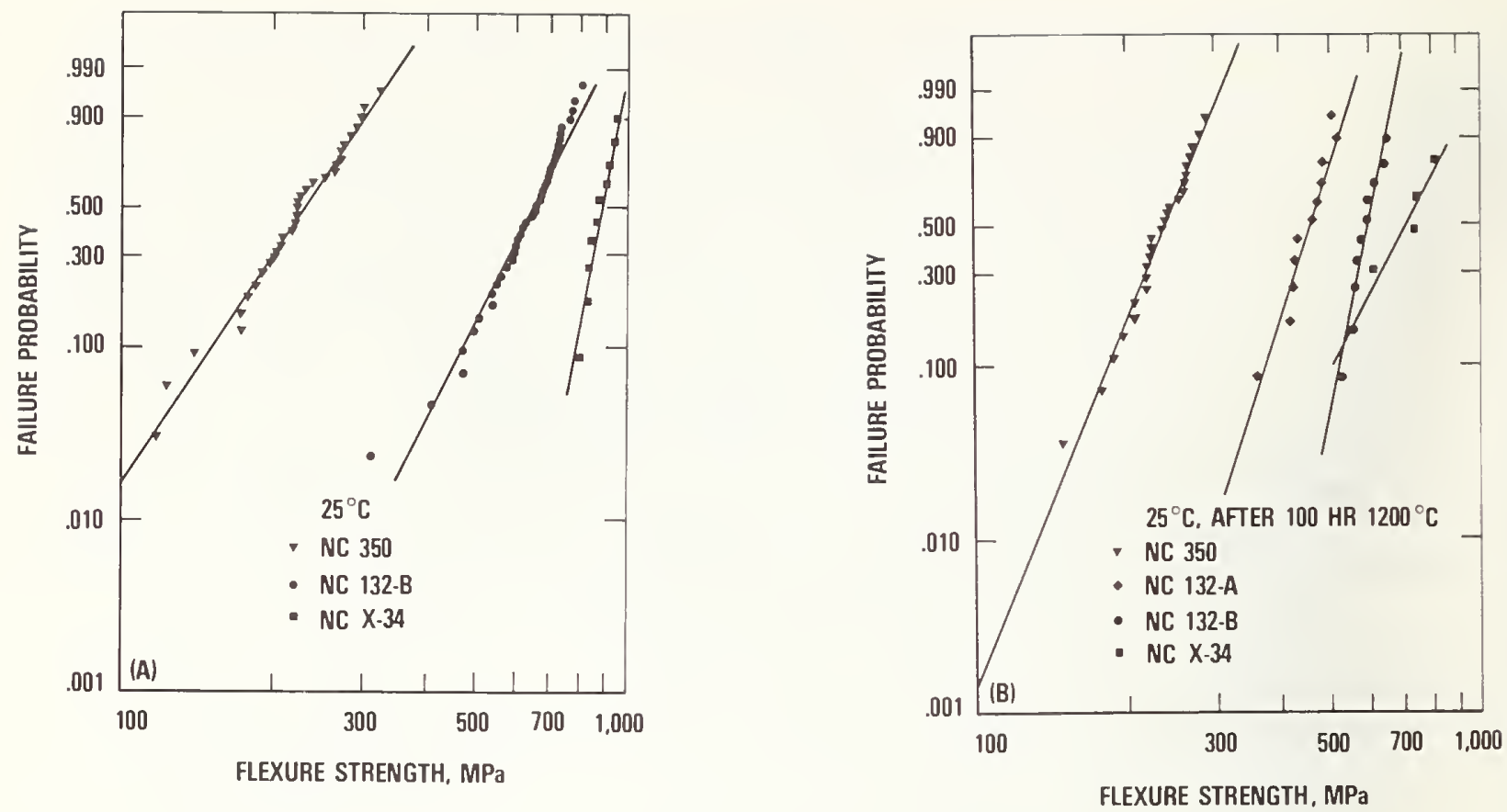

Figure 17. Comparison of strength of reaction bonded and 3 hot-pressed silicon nitride compositions: (a) as-received; (b) after 100 hours exposure at $1200^{\circ} \mathrm{C}$.
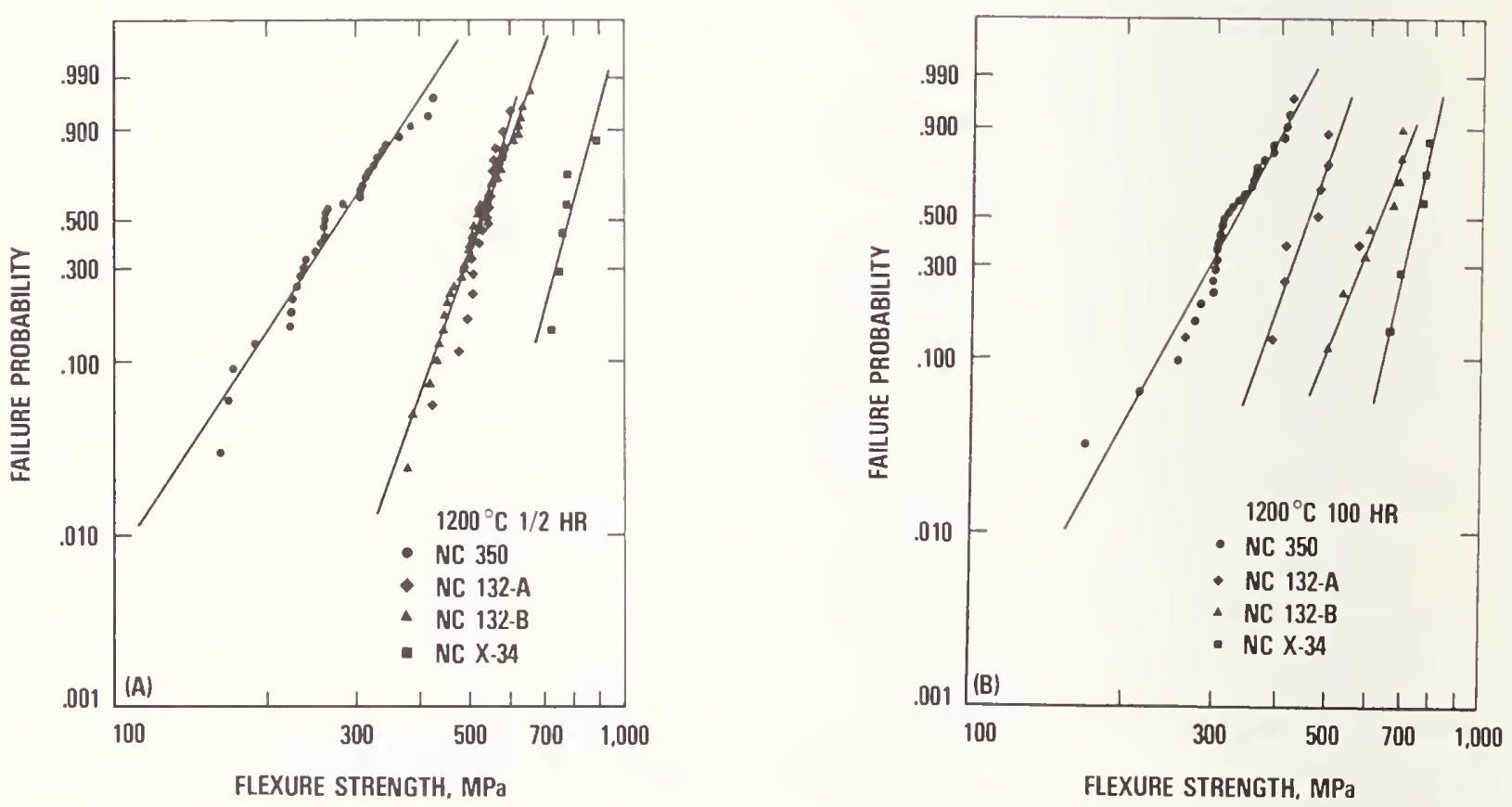

Figure 18. Comparison of the high temperature strength of reaction bonded and 3 hot-pressed composition of silicon nitride: (a) after 1/2 hour exposure; (b) after 100 hours exposure at $1200^{\circ} \mathrm{C}$. 
Silicon nitride materials development must parallel the development of component designs. The materials have not reached the optimum composition and microstructure for the turbine application. Many long-term use applications are dependent on having a reasonable expectation of long service lives and considerable materials analysis and development must be done to reach this goal.

\section{SECTION V \\ CONCLUSIONS}

Proof testing has been investigated as a means of assuring reliability and lifetimes of hot-pressed and reaction bonded silicon nitride for turbine engine applications. It was found that the proof test truncated the strength distribution at $25^{\circ} \mathrm{C}$ as predicted by theory. The proof test was not as successful in truncating the strength distribution of specimens exposed at $1200^{\circ} \mathrm{C}$, because the flaw population changed during exposure. This change in flaw population occurred because some flaws healed or were reduced in size, and other flaws were formed when the specimens oxidized.

Reaction bonded silicon nitride $(N C-350)$ showed an increase in strength as a result of exposure at $1200^{\circ} \mathrm{C}$. The oxidation formed a protective layer which healed surface cracks. A proof test scheme could be applied to this material.

The two billets of magnesia-doped, hot-pressed silicon nitride (NC-132) behaved differently. The strength distribution of billet A (of earlier manufacture) decreased as a result of exposure, whereas, the strength distribution of billet $B$ increased as a result of exposure. Thus, proof testing could be used for one billet but not for the other. Oxidation pits were produced in magnesia-doped, hot-pressed material and these pits become the strength limiting flaws. As a result of oxidation, 
flaws related to machining healed and could be removed eventually as the surface oxidized.

The yttria-doped $(\mathrm{NCX}-34)$ silicon nitride proof tests were not completed; however the strength distribution decreased as a result of exposure and it is unlikely that proof testing could be used for this billet. Examination of the microstructure before and after exposure showed that the oxidation produced significant microstructural changes in the near surface areas and these changes could be related to the strength changes. 
1. Wiederhorn, S. M., Evans, A. G., Fuller, E. R., and Johnson, H., "Application of Fracture Mechanics to Space Shuttle Windows," J. Am. Ceram. Soc. 57, 319-323 (1974).

2.. Ritter, J.E., Jr., and Meisel, J.A., "Strength and Failure Prediction for Glass and Ceramics," J. Am. Ceram. Soc. 59, 1112 (1976).

3. Evans, A. G., and Wiederhorn, S. M., "Proof Testing of Ceramic Materials - An Analytical Basis for Failure Prediction". Int. J. Fracture, 10, 379-392 (1974).

4. Evans, A. G., and Wiederhorn, S. M., "Crack Propagation and Failure Prediction in Silicon Nitride at Elevated Temperatures," J. Mat. Sci. 9, 270-278 (1974).

5. Evans, A. G., and Fuller, E. R., Jr., "Crack Propagation in Ceramic Materials Under Cyclic Loading Conditions," Met. Transactions 5, 27-33 (1974).

6. Davidge, R.W., McLaren, J.R., and Tappin, G., "StrengthProbability-Time (SPT) Relationships in Ceramics," J. Mat. Sci 8, 1699-1705 (1973).

7. Wiederhorn, S. M., Fuller, E. R., Jr., Mandel, J., and Evans, A. G., "An Error Analysis of Failure Prediction Techniques Derived from Fracture Mechanics," J. Am. Ceram. Soc. 59, 403-411 (1976).

8. Jacobs, D. F., and Ritter, J.E., Jr., "Uncertainty in Minimum Lifetime Predictions," J. Am. Ceram. Soc. 59, $481-487$ (1976).

9. Thorby, P. N., "Experimental Errors in Estimating Times to Failure," J. Am. Ceram. Soc. 59, 514-517 (1976).

10. Wiederhorn, S. M., "Reliability, Life Prediction and Proof Testing of Ceramics," in Ceramics for High Performance Applications, J. J. Burke, A. E. Gorum and R. N. Katz (Editors), Brook Hill Publishing Co. (1974), Chestnut Hill, Mass. pp 633-663.

11. Wiederhorn, S. M., Tighe, N. J., and Evans, A.G., Wivew Design Techniques for Brittle Materials," in Mechanical Properties of Ceramics for High Temperature Applications, AGARD Report No. 651, pp. 41-55, 1976.

12. Davidge, R. W., Evans, A. G., Gilling. D, and Wilyman, P.R., "Oxidation of Reaction Sintered Silicon Nitride and Effects on Strength," in Special Ceramics Vol. 5, 329-44 (1972). 
13. Lange, F. F., and Iskoe, J. L., "High Temperature Strength Behavior of Hot-Pressed $\mathrm{Si}_{3} \mathrm{~N}_{4}$ and $\mathrm{SiC}$ : Effects of Impurities," in Ceramics for High Performance Applications, ed. by J. J. Burke, A. E. Gorum, and R. N. Katz, Brook-Hill Publishing Co., pp 223-38 (1975).

14. Tighe, N. J., 'Microstructural Aspects of Deformation and Oxidation of Magnesia Doped Silicon Nitride," NBSIR Report No. 76-1153, Sept. 1976, in "Nitrogen Ceramics" F. R. Riley ed. Nordhoff International Publ., 1977 p 441-48.

15. Freiman, S. W., Mecholsky, J. J., McDonough, W. J., and Rice, R. W., "Effect of Oxidation on the Room Temperature Strength of Hot Pressed $\mathrm{Si}_{3} \mathrm{~N}_{4}-\mathrm{MgO}$ and $\mathrm{Si}_{3} \mathrm{~N}_{4}-\mathrm{ZrO}_{2}$ Bodies," To be published in: Ceramics for High Performance Applications-II, proc. of the Fifth Army Materials Technology Conf., Newport, Rhode Island, March 21-25, 1977.

16. Singhal, S. C., and Kossowsky, R., "Effect of Oxidation on the Flexural Strength of Hot-Pressed Silicon Nitride and Silicon Carbide," to be published in J. Am. Ceram. Soc.

17. Richerson, D. W., and Yonushonis, T. M., "Environmental Effects on the Strength of Silicon-Nitride Materials," to be published in the Proceedings of the ARPA/NAVSEAGarrett/Airesearch Ceramic Gas Turbine Engine Demonstration Program Review, held at the Main Maritime Academy, Aug. 1-4, 1977.

18. Wiederhorn, S. M., and Tighe, N. J., "Application of Proof Tests to Silicon Nitride," ERDA/Proceedings of Workshop on Ceramics for Advanced Heat Engines, Orlando, Fla.

19. Tighe, N. J., "The Structure of Slow Crack Interfaces in Silicon Nitride," J. Mat. Sci., 13 1455-63 1978 (NBSIR 76-1075).

20. Weibull, W., "A Statistical Theory of the Strength of Materials," Ingeniors Vetenskaps Akademian Handlingar, No. 151, 1931 .

21. Tighe, N. J., "Microstructure of Oxidized Silicon Nitride Proc. EMSA p 470-471, Claitors Publishing Co., Baton Rouge, La. (1974). 
N. J. Tighe and S. M. Wiederhorn

Examination of Fracture Interfaces in Silicon Nitride, Electron Microscopy Society of America, Los Vegas, Nevada, August 1975. N. J. Tighe

Structure of Fracture Interfaces in Silicon Nitride, American Ceramic Society Fall Meeting, Indianapolis, Ind., Sept. 1975. N. J. Tighe

Relationship between Crack Growth and Microstructure of Silicon Nitride, American Ceramic Society Fall Meeting, Indianapolis, Ind., Sept. 1975. N. J. Tighe

Microstructure of Silicon Nitride - Effects of Fracture and Oxidation, Joint Meeting American Society of Metals and American Institute of Metallurgical Engineers, Cincinnati, Ohio, November 1975. N. J. Tighe

Proof Testing of Silicon Nitride, NATO - Institute on Nitrogen Ceramics, Canterbury, England, August 1976. N. J. Tighe

Microstructural Aspects of Deformation and Oxidation of Silicon Nitride, NATO - Institute on Nitrogen Ceramics, Canterbury, England, August 1976. N. J. Tighe

Proof Testing of Silicon Nitride, USAF Meeting, Dayton, Ohio, October 1976. N. J. Tighe

Application of Proof Tests to Silicon Nitride, American Ceramic Society Fall Meeting, October 1976. N. J. Tighe

New Design Techniques for Brittle Materials, 43rd AGARD Meeting, Structures Panel, London, England, Sept. 1976. S. M. Wiederhorn

Application of Proof Tests to Silicon Nitride, ASME, Gas Turbine Conference, Philadelphia, PA., March 1977. N. J. Tighe

Effect of Flaw Generation on Proof Testing of Silicon Nitride, American Ceramic Society, Annual Meeting, Chicago, 111 inois, April 1977. N. J. Tighe

Characterization of Flaws Produced by Mechanical Grinding of $\mathrm{Si}_{3} \mathrm{~N}_{4}$, Electron Microscopy Society of America, Annual Meeting, Boston, Mass., August 1977. N. J. Tighe 
Is Proof Testing Applicable for High Temperature Survival of $\mathrm{Si}_{3} \mathrm{~N}_{4}$, American Ceramic Society Fall Meeting, Hyannis, Mass., Sept. 1977. N. J. Tighe

Effect of Service Conditions on Proof Testing of $\mathrm{Si}_{3} \mathrm{~N}_{4}$, American Society of Mechanical Engineers, Annual Meeting, Atlanta, Ga., Sept. 1977. N. J. Tighe

Application of Proof Testing to Silicon Nitride, Workshop on Ceramics for Advanced Heat Engines, Orlando, Fla., Jan.

1977. S. M. Wiederhorn

Effect of Flaw Generation on Proof Testing, Ceramic Gas Turbine Engine Demonstration Program Review, Castine, Maine, August 1977. S. M. Wiederhorn

Application of Proof Testing to Lifetime Predictions in Silicon Nitride, American Ceramic Society, Metal Systems Division, Cocoa Beach, Fla., Jan. 1978. S. M. Wiederhorn 
S. M. Wiederhorn, N. J. Tighe and A. G. Evans, 'New Design Techniques for Brittle Materials," in Mechanical Properties of Ceramics for High Temperature Application AGARD Report No. 651, pp 41-55, 1976.

N. J. Tighe, 'Microstructural Aspects of Deformation and Oxidation of Magnesia Doped Silicon Nitirde," (NBSIR 76-1153 Sept. 1976) in Nitrogen Ceramics, F. R. Riley ed., Noordhoff, Leyden 1977.

N. J. Tighe, S. M. Wiederhorn and L. R. Russell, "Application of Proof Tests to Silicon Nitride," NBSIR 77-1202, March (1977).

N. J. Tighe, 'The Structure of Slow Crack Interfaces in Silicon Nitride," NBSIR 76-1075, (1976), J. Mat. Sci., 13, $1455-1463,1978$.

S. M. Wiederhorn and N. J. Tighe, "Application of Proof Testing to Silicon Nitride," ERDA Proceedings of Workshop on Ceramics for Advanced Heat Engines, Orlando, Fla., (Jan. 1977).

S. M. Wiederhorn and N. J. Tighe, "Effect of Flaw Generation on Proof Testing," (NBSIR 77-1408) Proceedings Ceramic Gas Turbine Engine Demonstration Program Review, Castine, Maine

S. M. Wiederhorn and N. J. Tighe, "Proof Testing of Silicon Nitride," J. Mat. Sci., 13, 1781-1793, (1978). 
